\title{
The role and proteomic analysis of ethylene in hydrogen gas- induced adventitious rooting development in cucumber (Cucumis sativus L.) explants
}

\author{
Dengjing Huang ${ }^{1}$, Biting Bian ${ }^{1}$, Meiling Zhang ${ }^{2}$, Chunlei Wang ${ }^{1}$, Changxia Li ${ }^{1}$, Weibiao Liao ${ }^{\text {Corresp. } 1}$ \\ ${ }^{1}$ College of Horticulture, Gansu Agricultural University, Lanzhou, PR China, Lanzhou, China \\ 2 College of Science, Gansu Agricultural University, Lanzhou, China \\ Corresponding Author: Weibiao Liao \\ Email address: liaowb@gsau.edu.cn
}

Previous studies have shown that both hydrogen gas $\left(\mathrm{H}_{2}\right)$ and ethylene $(\mathrm{ETH})$ play positive roles in plant adventitious rooting. However, the relationship between $\mathrm{H}_{2}$ and ETH during this process has not been explored and remains insufficiently understood. In this study, cucumber (Cucumis sativus L.) was used to explore the proteomic changes in $\mathrm{ETH}-\mathrm{H}_{2}-$ induced rooting. Our results show that hydrogen-rich water (HRW) and ethylene-releasing compound (ethephon) at proper concentrations promote adventitious rooting, with maximal biological responses occurring at $50 \% \mathrm{HRW}$ or $0.5 \mu \mathrm{M}$ ethephon. ETH inhibitors aminoethoxyvinylglycine (AVG) and $\mathrm{AgNO}_{3}$ cause partial inhibition of adventitious rooting induced by $\mathrm{H}_{2}$, suggesting that ETH might be involved in $\mathrm{H}_{2}$-induced adventitious rooting. According to two-dimensional electrophoresis (2-DE) and mass spectrometric analyses, compared with the control, 9 proteins were up-regulatedwhile 15 proteins were downregulatedin HRW treatment; 4 proteins were up-regulated while 10 proteins were downregulated in ethephon treatment; and 1 protein was up-regulated while 9 proteins were down-regulated in HRW+AVG treatment. Six of these differentially accumulated proteins were further analyzed, including photosynthesis -related proteins [ ribulose-1,5bisphosphate carall boxylase smsubunit (Rubisco), sedoheptulose-1,7-bisphosphatase (SBPase), oxygen-evolving enhancer protein (OEE1)], amino and metabolism-related protein [ threonine dehydratase (TDH)], stress response-related protein [cytosolic ascorbate peroxidase (CAPX)], and folding, modification and degradation-related protein [ protein disulfide-isomerase (PDI)]. Moreover, the results of real-time PCR about the mRNA levels of these genes in various treatments were consistent with the 2-DE results. Therefore, ETH may be the downstream signaling molecule during $\mathrm{H}_{2}$ - induced adventitious rooting and proteins Rubisco, SBPase, OEE1, TDH, CAPX and PDI may play important roles during the process. 
1 The role and proteomic analysis of ethylene in hydrogen gas-

2 induced adventitious rooting development in cucumber

3 (Cucumis sativus L.) explants

4 Dengjing Huang ${ }^{1}$, Biting Bian ${ }^{1}$, Meiling Zhang ${ }^{2}$, Chunlei Wang ${ }^{1}$, Changxia Li ${ }^{1}$, Weibiao

5 Liao $^{1}$

6

7

$8 \quad{ }^{1}$ College of Horticulture, Gansu Agricultural University, Lanzhou, PR China

$9 \quad{ }^{2}$ College of Science, Gansu Agricultural University, Lanzhou, PR China

10

11 Corresponding author:

12 Weibiao Liao

13 Mailing address:

14 College of Horticulture, Gansu Agricultural University, Anning District, Lanzhou, China

15 E-mail address: liaowb@gsau.edu.cn 
17 Abstract

Previous studies have shown that both hydrogen gas $\left(\mathrm{H}_{2}\right)$ and ethylene $(\mathrm{ETH})$ play positive roles in plant adventitious rooting. However, the relationship between $\mathrm{H}_{2}$ and ETH during this process has not been explored and remains insufficiently understood. In this study, cucumber (Cucumis sativus $\mathrm{L}$.) was used to explore the proteomic changes in ETH- $\mathrm{H}_{2}$-induced rooting. Our results show that hydrogen-rich water (HRW) and ethylene-releasing compound (ethephon) at proper concentrations promote adventitious rooting, with maximal biological responses occurring at $50 \%$ $\mathrm{HRW}$ or $0.5 \mu \mathrm{M}$ ethephon. ETH inhibitors aminoethoxyvinylglycine (AVG) and $\mathrm{AgNO}_{3}$ cause partial inhibition of adventitious rooting induced by $\mathrm{H}_{2}$, suggesting that ETH might be involved in $\mathrm{H}_{2}$-induced adventitious rooting. According to two-dimensional electrophoresis (2-DE) and mass spectrometric analyses, compared with the control, 9 proteins were up-regulated while 15 proteins were down-regulated in HRW treatment; 4 proteins were up-regulated while 10 proteins were down-regulated in ethephon treatment; and 1 protein was up-regulated while 9 proteins were down-regulated in HRW+AVG treatment. Six of these differentially accumulated proteins were further analyzed, including photosynthesis-related proteins [ribulose-1,5-bisphosphate carall boxylase smsubunit (Rubisco), sedoheptulose-1,7-bisphosphatase (SBPase), oxygenevolving enhancer protein (OEE1)], amino and metabolism-related protein [threonine dehydratase (TDH)], stress response-related protein [cytosolic ascorbate peroxidase (CAPX)], and folding, modification and degradation-related protein [protein disulfide-isomerase (PDI)]. Moreover, the results of real-time PCR about the mRNA levels of these genes in various treatments were consistent with the 2-DE results. Therefore, ETH may be the downstream signaling molecule during $\mathrm{H}_{2}$ - induced adventitious rooting and proteins Rubisco, SBPase, OEE1, TDH, CAPX and PDI may play important roles during the process.

Keywords: Cucumber, Adventitious root formation, Hydrogen gas, Ethylene, Proteomics

\section{Introduction}

Adventitious roots are formed from non-root tissue such as leaves, stems and hypocotyls. Adventitious roots usually increase the area of roots, heightening their abilities to absorb nutrients and support plants. Additionally, adventitious roots play an important role in promoting the vegetative propagation of fine varieties and the agriculture and forestry industries. Thus, exploring the mechanism of adventitious root formation is both necessary and meaningful. The roles of signal molecules in adventitious root development have recently become a hot topic of research. Some signal molecules including auxin (Bai et al. 2012), ethylene (Pan et al. 2002), carbon monoxide (CO; Xuan et al. 2008), nitric oxide (NO), hydrogen peroxide $\left(\mathrm{H}_{2} \mathrm{O}_{2}\right), \mathrm{Ca}^{2+}$ ions, calmodulin (Liao et al. 2012), hydrogen sulfide $\left(\mathrm{H}_{2} \mathrm{~S}\right.$; Lin et al. 2012), hydrogen $\left(\mathrm{H}_{2}\right.$; Lin et al. 2014) and methane (Cui et al. 2015) have been associated with the initiation and development of adventitious roots. More studies about signal transduction will help us understand the 
57

58

59

60

61

mechanisms involved in adventitious rooting.

Despite its simple two-carbon structure, ethylene (ETH) plays an important role in regulating plant growth and development. ETH may induce diverse effects throughout the plant life cycle, including seed germination, flower senescence and fruit ripening (Khan et al. 2017). ETH is also involved in the plant's defense reactions against pathogens or elicitor attacks, and in its responses to abiotic stresses such as wounding, hypoxia, chilling, freezing and flooding (Khan et al. 2017), indicating that ETH might be a regulator of plant growth, development and stress responses.

Since it was firstly discovered that ethylene stimulates adventitious root formation, there have been a great number of studies on the topic. Riov and Yang (1989) investigated the role of ETH in adventitious root formation in auxin-induced cuttings of Vigna radiata (L.) and found that ETH increased the number of adventitious roots while aminoethoxyvinylglycine (AVG, a kind of ETH inhibitor) significantly inhibited rooting. Pitts et al. (1998) used the mutations of ETH and auxin to prove that auxin and ETH are required for normal root hair elongation. Clark et al. (1999) found that aboveground adventitious roots were produced in few ETH-insensitive neverripe tomato plants and ETH- insensitive transgenic petunia plants compared to wild type plants, and proved the positive role of ETH in adventitious root formation. Similar results were obtained from sunflower cuttings (Liu et al. 1990), mung bean hypocotyl cuttings (Pan et al. 2002), Panax ginseng C.A. Meyer (Bae et al. 2006), and globe artichoke seedlings (Shinohara et al. 2016). However, some researchers have indicated that ETH can inhibit adventitious root formation. Biondi et al (1990) showed that in Prunus avium shoot cultures, the addition of ethylene precursor1-aminocyclopropane-1-carboxylic acid (ACC) decreased the rooting percentage while AVG caused roots to form. Some years later, the studies of Ma et al. (1998) demonstrated that $\mathrm{AgNO}_{3}$ (another kind of ETH inhibitor) and AVG increased the number of roots in apple shoots.

Hydrogen gas $\left(\mathrm{H}_{2}\right)$, the lightest gas, is a colorless, odorless, and tasteless diatomic gas in nature. Ohsawa et al. (2007) found that $\mathrm{H}_{2}$ can be used as an effective antioxidant therapy in the partial brain of rat, and since then, the use of $\mathrm{H}_{2}$ in the prevention and control of various diseases has been a hot topic of research (Hong et al. 2010). More recently, the physiological functions of $\mathrm{H}_{2}$ in higher plants have also been studied. $\mathrm{H}_{2}$ has often been shown to respond to stresses like salt stress, drought stress, heavy metal toxicity, oxidative stress and UV-A irradiation (Jin et al. 2013, Zeng et al. 2014, Su et al. 2014), and delaying fruit senescence (Hu et al. 2014) and inducing stomatal closure (Xie et al. 2014). Recently, another function of $\mathrm{H}_{2}$ was discovered: the promotion of adventitious root occurrence. The results of Lin et al. (2014) demonstrated that $50 \%$ HRW could mimic hemin function and restore cucumber adventitious root formation by mediating the expression of auxin signaling-related and adventitious root formation-related genes. Zhu et al. (2016) has reported that HRW treatment increases the content of nitric oxide (NO) and up-regulated cell cycle activation during adventitious root formation. Moreover, Cao et al. (2017) 
97

98

99

100

101

102

103

104

105

106

107

108

109

110

111

112

113

114

115

116

117

118

119

120

121

122

123

124

125

126

127

128

129

130

131

132

133

134

135

136

suggested that HRW is involved in regulating auxin-induced lateral root formation by modulating NR-dependent NO synthesis.

Based on the results of the studies summarized above, ETH and $\mathrm{H}_{2}$ are involved in adventitious root formation. However, the precise mechanism remains unclear. In this study, we hypothesized the exists of a relationship between ETH and $\mathrm{H}_{2}$ during adventitious rooting in cucumber (Cucumis sativus L.).

To prove this hypothesis, ETH inhibitors were used. Proteomic methods have been widely applied to determine genetic and cellular function at the protein level. Many plant proteomic studies using 2-DE have found differential proteins during somatic embryogenesis, seed germination, adventitious root formation, flowering transition, and stem dormancy. Proteomic analysis has also proven useful in the identification of proteins associated with a range of biotic and abiotic stress responses (Cui et al. 2015, Xu et al. 2016). Therefore, 2-DE and matrixassisted laser desorption/ionization time-of-flight/time-of-flight (MALDI-TOFTOF) were used to compare quantitative and qualitative changes that occurred during ethylene- $\mathrm{H}_{2}$-induced adventitious rooting in the proteome. Through the comprehensive analysis of the function and content of differential proteins under different treatments and the expression of genes related to these proteins, we speculate that ETH possibly affect the expression of some proteins and the expression of their related genes. The results provide new insights into the physiological and molecular mechanisms associated with adventitious root development.

\section{Materials and Methods}

\section{Plant materials and treatments}

Cucumber (Cucumis sativus L. var. 'Xinchun 4') seeds were purchased from Gansu Agricultural Institute (Lanzhou, China). The seeds were surface-sterilized in 5\% sodium hypochlorite for 10 min and washed with water. The seeds were germinated on filter paper with distilled water in Petri dishes (15 cm-diameter, $2.5 \mathrm{~cm}$-deep) and maintained at $25 \pm 1{ }^{\circ} \mathrm{C}$ for $7 \mathrm{~d}$ with a $14-\mathrm{h}$ photoperiod (photosynthetically active radiation $=200 \mu \mathrm{mol} \mathrm{m}^{-2} \mathrm{~s}^{-1}$ ). The 7-day-old seedlings with primary roots removed were used as explants and were maintained under the same temperature and photoperiod conditions for another 7 days in the presence of different media as indicated below. We described these different treatments as (I) HRW $(0,1 \%, 10 \%, 50 \%$ and 100\%); (II) ethephon (0, 0.1, 0.5, 1, 10 and $50 \mu \mathrm{mol} \cdot \mathrm{L}^{-1}$ ); (III) AVG (aminoethoxyvinylglycine, $0,0.1,1,5$ and $\left.10 \mu \mathrm{mol} \cdot \mathrm{L}^{-1}\right)$; (IV) $\mathrm{AgNO}_{3}$ and $\mathrm{NaNO}_{3}\left(0,0.1,0.3\right.$ and $0.5 \mu \mathrm{mol} \cdot \mathrm{L}^{-1}$ ); and (V) $50 \%$ $\mathrm{HRW}+0.5 \mu \mathrm{mol} \cdot \mathrm{L}^{-1}$ ethephon, $1 \mu \mathrm{mol} \cdot \mathrm{L}^{-1} \mathrm{AVG}$, or $0.1 \mu \mathrm{mol} \cdot \mathrm{L}^{-1} \mathrm{AgNO}_{3}$. After applying treatment explants were sampled to determine root number per explants. The hypocotyls (5-mmlong segments of the hypocotyl base where the adventitious root develops) of the explants after $48 \mathrm{~h}$ of treatment were immediately used or frozen in liquid nitrogen for further analysis.

\section{Preparation of hydrogen-rich water (HRW)}

Purified $\mathrm{H}_{2}$ gas $(99.99 \%$, v/v) generated from a hydrogen gas generator (QL-300, Saikesaisi 
137 Hydrogen Energy Co., Ltd., China) was bubbled into distilled water at a rate of $300 \mathrm{~mL} \mathrm{~min}^{-1}$ for

138

139

140

141

142

143

144

145

146

147

148

149

150

151

152

153

154

155

156

157

158

159

160

161

162

163

164

165

166

167

168

169

170

171

172

173

174

175

176

177

$30 \mathrm{~min}$. The corresponding HRW was rapidly diluted to the required saturations (Zhu et al. 2016). The $\mathrm{H}_{2}$ concentration analyzed by gas chromatography in freshly prepared HRW was $0.68 \mathrm{mM}$, which was defined as $100 \% \mathrm{HRW}$, and was maintained at a relatively constant level in $25{ }^{\circ} \mathrm{C}$ for at least $12 \mathrm{~h}$.

\section{Quantification of ethylene}

ETH was detected by a gas chromatographic analyzer (SP-3420A, Beifenruili Inc., China). Five fresh cucumber explants were placed in $20 \mathrm{~mL}$ vials, stoppered with secure rubber caps, and containing $1 \mathrm{~mL}$ culture solution. These vials had the same conditions as before when the seedlings grew for $12 \mathrm{~h}$. A gas sample $(2.5 \mathrm{~mL})$ was extracted and injected into a gas chromatograph, which was fitted with a GDX-502 column $(2 \mathrm{~m} \times 3.2 \mathrm{~mm})$ and a flame ionization detector. The temperature of the column, inlet and detector were 50,140 and $240{ }^{\circ} \mathrm{C}$, respectively. The flow rate of nitrogen gas, the carrier gas, was $30 \mathrm{~mL} \cdot \mathrm{min}^{-1}$. ETH production was expressed as $\mu \mathrm{L} \cdot \mathrm{h}^{-1} \cdot \mathrm{kg}^{-1} \mathrm{FW}$.

\section{Protein extraction}

The trichloroacetic acid (TCA)/acetone method was used to extract the total protein (Damerval et al. 1986). Approximately $2.0 \mathrm{~g}$ of the sample was manually ground to a fine powder in liquid nitrogen with $0.04 \mathrm{~g}$ crosslinking polyvingypyrrolidone (PVPP) and split into 6 tubes. The powder was suspended in $2 \mathrm{~mL}$ of acetone containing $10 \% \mathrm{w} / \mathrm{v}$ TCA and $0.07 \% \mathrm{v} / \mathrm{v} \beta$ mercaptoethanol $(\beta-\mathrm{ME})$. After precipitation at $-20^{\circ} \mathrm{C}$ for at least $8 \mathrm{~h}$ or overnight, the pellet was collected by centrifuging at $12,000 \times \mathrm{g}$ for $30 \mathrm{~min}$. Then the powder was suspended in $2 \mathrm{~mL}$ of ice cold acetone $\left(-20^{\circ} \mathrm{C}\right)$ containing $0.07 \%(\mathrm{v} / \mathrm{v}) \beta$-ME at $4^{\circ} \mathrm{C}$ for $1 \mathrm{~h}$, then centrifuged at $12,000 \times g$ for $20 \mathrm{~min}$, and washed two times. The powder was then suspended in $2 \mathrm{~mL}$ of $80 \%$ acetone containing $0.07 \%(\mathrm{v} / \mathrm{v}) \beta-\mathrm{ME}$ at $4^{\circ} \mathrm{C}$ for $30 \mathrm{~min}$, centrifuged at $12,000 \times \mathrm{g}$ for $15 \mathrm{~min}$, and washed two times. The supernatant was removed and the pellets were dried in a freezer dryer. After airdrying, the powder was dissolved in a hydration solution [7 M urea, $2 \mathrm{M}$ thiourea, 4\% (w/v) 3[(3-Cholamidopropyl)dimethylammonio]propanesulfonate (CHAPS), 1\% (w/v) DL-

Dithiothreitol (DTT)] at a normal temperature for $2 \mathrm{~h}$, then centrifuged at $12,000 \times \mathrm{g}$ for $30 \mathrm{~min}$. The supernatant was the total protein. The protein content was determined calorimetrically using bovine serum albumin as a standard. Protein samples were stored at $-80^{\circ} \mathrm{C}$ for further analysis.

\section{2-DE and staining}

Sample aliquots containing protein were applied to $17 \mathrm{~cm} \mathrm{pH} \mathrm{4-7} \mathrm{immobilized} \mathrm{pH}$ gradient (IPG) strips, and small volumes of lysis buffer were added to the sample aliquots. Isoelectric focusing was performed on a PROTEAN IEF Cell system (Bio-Rad) for a total of $76 \mathrm{kVh}$ at $20^{\circ} \mathrm{C}$. The voltage was set at $50 \mathrm{~V}$ for $14 \mathrm{~h}, 250 \mathrm{~V}$ for $1.5 \mathrm{~h}, 1000 \mathrm{~V}$ for $2.5 \mathrm{~h}, 9000 \mathrm{~V}$ for $5 \mathrm{~h}$, and were run at $90000 \mathrm{~V}$ and then $500 \mathrm{~V}$ for a maximum of $24 \mathrm{~h}$. Next, the gels were run using the PROTEAN II xi cell system (Bio-Rad) at $100 \mathrm{~V}$ for $1 \mathrm{~h}$, followed by $250 \mathrm{~V}$ until the bromophenol blue nearly reached the bottom of the gel. After electrophoresis, staining was performed by placing

Peer) reviewing PDF | (2019:07:39221:3:0:NEW 4 Mar 2020) 
178

179

180

181

182

183

184

185

186

187

188

189

190

191

192

193

194

195

196

197

198

199

200

201

202

203

204

205

206

207

208

209

210

211

212

213

214

215

the gels into Coomassie brilliant blue solution for $17 \mathrm{~h}$. To provide support for the cucumber proteomics, we performed system optimization of the pH IPG strips, loading quantity and separation gel concentration. The protein spots on the $\mathrm{pH} 3-10$ gels show that the acidic side $(\mathrm{pH}$ 3-5) in the region of the protein particle distribution was less than alkaline side ( $\mathrm{pH} 9-10)$ area, forming a longitudinal tail (Fig. Sl). Most of the explant protein spots were focused in the $\mathrm{pH} 4-$ 7 region. The results showed that $800 \mu \mathrm{g}$ of loading quantity was optimal (Fig. S2), and 12\% $(w / v)$ gel concentration separation was the best choice to obtain the good resolving effect (Fig. S3). The results also showed that $\mathrm{pH} 4-7$ IPG strips (17 cm, nonlinear; Bio-Rad), $800 \mu \mathrm{g}$ loading quantity and $12 \%(\mathrm{w} / \mathrm{v})$ separation gel concentration was the most suitable combination for isoelectric focusing of the explants' total protein in cucumber.

\section{Image analysis and protein identification}

The proteins in the gels were visualized by CBB-G250 staining. The gel images were obtained at a resolution of 300 dpi and then imported into PDQuest 8.0 (Bio-Rad). The protein spots were excised from CBB-stained preparative polyacrylamide gels. The MS and MS/MS data for protein identification were obtained with a MALDI-TOFTOF instrument (Zhang et al. 2015). The database NCBI (https://www.ncbi.nlm.nih.gov/) were used to match and identified the protein spots. According to Gene Ontology and UniProt Protein Knowledgebase (http://www.uniprot.org/), the gene ontology (GO) analysis was performed on the proteins identified by mass spectrometry. The proteomic data have been uploaded to the Supplemental Files.

\section{Total RNA extraction and real time PCR}

Total RNA from each sample was isolated using a MiniBEST Plant RNA Extraction Kit (TaKaRa, Beijing, China). Total RNA was reverse-transcribed by using the PrimeScript ${ }^{\mathrm{TM} R T}$ Master Mix (Perfect Real Time) according to the manufacturer's manual (Takara, Beijing, China). Quantitative real-time PCR was performed with a LightCycler 96 Real- Time PCR System (Roche, Switzerland) using SYBR ${ }^{\circledR}$ Premix Ex Taq ${ }^{\mathrm{TM}}$ II (TaKaRa, Beijing, China). Every PCR reaction was performed twice, with three independent replicates. The relative expression level of each gene was acquired using a comparative $\mathrm{Ct}$ method followed by internal control normalization. PCR was carried out in $20 \mu \mathrm{L}$ volumes using the following amplification protocol: $10 \mathrm{~s}$ at $95^{\circ} \mathrm{C}$, followed by 40 cycles of $15 \mathrm{~s}$ at $95^{\circ} \mathrm{C}$, and then annealing at $60^{\circ} \mathrm{C}$ for $30 \mathrm{~s}$. The relative quantization of gene expression was calculated and normalized to Actin. The expression change was calculated using the $2^{-\Delta \Delta c t}$ method. The primers used for PCR analysis are listed in Table 1.

\section{Results}

Effects of different concentrations of HRW and ethephon on adventitious root development

Peer) reviewing PDF | (2019:07:39221:3:0:NEW 4 Mar 2020) 
216 To understand the effect of $\mathrm{H}_{2}$ on adventitious root development, cucumber explants were treated

217 with different concentrations of $\operatorname{HRW}(0,1 \%, 10 \%, 50 \%$ and 100\%). As shown in Fig. 1,

218 different concentrations of HRW affected the development of adventitious roots. The cucumber

219 explants treated with 50\% and 100\% HRW produced more adventitious roots than the control

220 explants, but the root number under the 1\% HRW treatment was significantly lower than that of

221 the control. The maximum root number was observed with 50\% HRW treatment (Fig. 1) and this

222 was used for further study.

223

224

225

226

227

228

229

230

231

232

233

234

235

236

237

238

239

240

241

242

243

Different concentrations of ethephon, ETH-releasing compound, also had significant effects on the development of adventitious roots (Fig. 2). Lower concentrations of ethephon $(0.1,0.5,1$, and $\left.10 \mu \mathrm{mol} \cdot \mathrm{L}^{-1}\right)$ increased adventitious root number, while the high concentration $\left(50 \mu \mathrm{mol} \cdot \mathrm{L}^{-1}\right)$ significantly inhibited adventitious roots. The maximum inducible response was observed in 0.5 $\mu \mathrm{mol} \cdot \mathrm{L}^{-1}$ ethephon-treated explants (Fig. 2). Thus, we used $0.5 \mu \mathrm{mol} \cdot \mathrm{L}^{-1}$ to further investigate the role of ethylene in rooting.

\section{Effects of ethylene inhibitors AVG and $\mathrm{AgNO}_{3}$ on $\mathrm{H}_{2}$-induced adventitious root development}

To further study the function of ETH in adventitious root formation, ethylene inhibitors were used. Results shown in Fig. S4 and Fig. S5 indicate that various concentrations of ETH synthesis inhibitors $\mathrm{AVG}$ and $\mathrm{AgNO}_{3}$ have negative effects on rooting. We used $1 \mu \mathrm{mol} \cdot \mathrm{L}^{-1} \mathrm{AVG}$ and 0.1 $\mu \mathrm{mol} \cdot \mathrm{L}^{-1} \mathrm{AgNO}_{3}$ for further study. As seen in Fig. 3, explants treated with either HRW or ethephon alone showed improved adventitious rooting when compared with the control. Although explants treated with HRW plus ethephon had higher root number, they were not significantly higher than explants treated with either HRW or ethephon alone. When AVG (inhibitor of ETH synthesis) or $\mathrm{AgNO}_{3}$ (an ETH action inhibitor) was added to the HRW, the inducing effects of ethephon on adventitious rooting were reversed (Fig. 3). Thus, we deduce that ETH might be involved in $\mathrm{H}_{2}$-induced adventitious root development.

\section{Effect of $\mathrm{H}_{2}$ on ETH production and ETH-related genes' expression}

As shown in Fig. 4 A, the production of ETH in 50\% HRW treatment was about double that of the control. Moreover, the results in Fig. $4 B$ indicate that HRW treatment significantly enhances the gene expression of CSACS3. When compared with the control, the expression of CsACO1 was noticeably improved by HRW. These consistent results suggested that ETH might function in the downstream of $\mathrm{H}_{2}$-induced adventitious root formation.

\section{Comparison of 2-DE gels and protein identification during adventitious root development} All 70 protein spots from the 2-DE gels showed statistical differences. However, due to limited genomic information about $C$. sativus in the NCBI database, only 48 differentially expressed protein spots could be identified by MALDI TOF/TOF MS/MS with a significant search score, shown in Table 2 and Fig. 5. Out of the 48 differential proteins selected by analysis, 15 proteins were down-regulated while 9 (spot 203, 230, 858, 158, 975, 1116, 1132, 626 and 1140) were up- 
257

258

259

260

261

262

263

264

265

266

267

268

269

270

271

272

273

274

275

276

277

278

279

280

281

282

283

284

285

286

287

288

289

290

291

292

293

294

295

296

297

regulated in the HRW treatment; 10 proteins were down-regulated and 4 (spot 2129, 1908, 1561, 1284) were up-regulated in the ethephon treatment; 9 proteins were down-regulated whiles 1 (spot 239) was up-regulated in the HRW + AVG treatment. Table 2 shows a list of the putative names of proteins, matching species, protein score, accession number, molecular weights (MW), isoelectric point (PI), peptides count and Up/Down regulation. The results indicate that matching species listed above originated from the cucumber database, with molecular weights ranging from 9.4 to $75.3 \mathrm{KDa}$, PI of spots ranging from 4.31 to 8.6, protein scores ranging from 62 to 905, and matched peptide counts between 2 and 27.

\section{Functional analysis of the six identified proteins}

Forty-eight protein spots were identified using the annotated NCBI database, and these were designated as 41 known proteins and seven 7 unknown proteins. Using the Gene Ontology and UniProt Protein Knowledgebase, all of the identified proteins were categorized into eight 8 major groups (Fig. 6). Among these, Seventeen (17) photosynthesis-related proteins constituted the largest percentage $(35.4 \%)$, followed by six energy metabolism-related proteins $(12.5 \%)$, six translation and transcription-related proteins (12.5\%), six protein folding, modification and degradation-related proteins $(12.5 \%)$, three stress response-related proteins $(6.3 \%)$, two amino and metabolism-related proteins $(4.2 \%)$, one cellular cytoskeleton-related proteins $(2.1 \%)$, and seven unknown proteins $(14.6 \%)$.

The differentially expressed proteins were identified using mass spectrometry and GO ontology analysis. These proteins were distributed in 3 categories: "biological process" (the largest group), "cellular component"' and "molecular function"' (the smallest group). As shown in Fig. 7, 4 categories of proteins were identified in the biological process, comparing cellular process, metabolic process, response to stimulus and single-organism process; 3 categories of proteins were identified in molecular function, comparing: catalytic activity, transporter activity and binding; and 6 categories of proteins were identified in the cellular components, including organelles, cell parts and so on.

Out of the 41 proteins with known functions, 5 proteins were up-regulated in HRW or ethephon treatment, and were down-regulated in HRW + AVG treatment. these included ribulose-1,5bisphosphate carboxylase small subunit (Rubisco), sedoheptulose-1,7-bisphosphatase (SBPase), threonine dehydratase (TDH), cytosolic ascorbate peroxidase (CAPX), and protein disulfideisomerase (PDI) (Table 3). The oxygen-evolving enhancer protein (OEE1) was down-regulated under HRW or ethephon treatment and up-regulated under HRW + AVG treatment.

\section{Validation of the identified proteins at the mRNA level during adventitious root development}

The mRNA levels of Rubisco, SBPase, TDH, CAPX and PDI genes under HRW or ethephon treatment were significantly higher than those of the control (Fig. 8). However, HRW + AVG treatment caused significant reduction in the expression of these genes. The mRNA levels of OEE1 increased significantly in the explants treated with HRW or ethephon, and decreased 
298

299

300

301

302

303

304

305

306

307

308

309

310

311

312

313

314

315

316

317

318

319

320

321

322

323

324

325

326

327

328

329

330

331

332

333

334

335

336

337

significantly in the explants treated with HRW+AVG. The changes of the mRNA levels of 6 genes were consistent with protein levels observed in the 2-DE results.

\section{Discussion}

Since Renwick et al. (1964) first reported that $\mathrm{H}_{2}$ could promote germination, the function of $\mathrm{H}_{2}$ in plants has been extensively investigated. Recently, $\mathrm{H}_{2}$ has been linked to a wide variety of physiological processes in plants, ranging from the control of developmental processes to the regulation responses to abiotic stresses (Xie et al. 2012, Hu et al. 2014, Wu et al. 2015, Chen et al. 2017). Lin et al. (2014) and Zhu et al. (2017) reported that $\mathrm{H}_{2}$ plays positive roles in adventitious root development. In our study, suitable concentrations of exogenous $\mathrm{H}_{2}$ significantly promoted the formation of adventitious roots in cucumber. Moreover, ETH was also found to be involved in adventitious rooting. Previous studies showed that ETH stimulated adventitious root formation in some crops including mung bean (Pan et al. 2002), sunflower (Liu et al. 1990) and marigold (Jin et al. 2017). Xu et al. (2017) revealed that ETH increased the formation of adventitious root in dose-dependent experiments. Our results suggested that exogenous ETH and $0.5 \mu \mathrm{mol} \cdot \mathrm{L}^{-1}$ ethephon significantly enhanced adventitious rooting. Evidently, both $\mathrm{H}_{2}$ and ETH can induce adventitious rooting, but the interaction between $\mathrm{H}_{2}$ and ETH during that process remains poorly understood. The results in this study suggest that ETH is involved in the $\mathrm{H}_{2}$-induced adventitious rooting process and might function at the downstream of $\mathrm{H}_{2}$.

We found that the selected ethylene inhibitors $\mathrm{AVG}$ and $\mathrm{AgNO}_{3}$, caused partial inhibition of $\mathrm{H}_{2}$ induced adventitious root development. When comparing HRW and the control in the production of ETH and the expression of two ETH-related genes, the HRW treatment was obviously higher than the control. These results suggest that ETH may be a downstream signal molecule in $\mathrm{H}_{2}$ induced adventitious root development.

To further prove that ETH is involved in $\mathrm{H}_{2}$-induced adventitious root formation, we used proteomic analysis, which allowed us to identify proteins whose expression was altered during adventitious rooting particularly in regard to $\mathrm{H}_{2}$ and ETH treatments. The results of proteomic analysis showed that there were 41 differential proteins with known functions successfully identified in the adventitious root formation of cucumber. They were distributed among 3 categories. We also found 6 proteins, Rubisco, SBPase, TDH, CAPX, PDI and OEE1, to be used for further study.

It is known that Rubisco, SBPase and OEE1 proteins are related to the photosynthetic process. Rubisco is a vital enzyme associated with carbon fixation (Xu et al. 1994) and its catalytic inefficiencies often limit plant productivity (Andersson et al. 2008, Gunn et al. 2017). SBPase has been shown to increase photosynthetic capacity and plant yield and it also promotes the growth of plants at the early growth stage (Ogawa et al. 2015). Our results show that Rubisco 
338

339

340

341

342

343

344

345

346

347

348

349

350

351

352

353

354

355

356

357

358

359

360

361

362

363

364

365

366

367

368

369

370

371

372

373

374

375

376

377

378

and SBPase expression were up-regulated under HRW or ethephon treatment, suggesting that $\mathrm{H}_{2}$ and ETH may increase the efficiency of photosynthesis in explants by enhancing Rubisco and SBPase expression during rooting. ETH inhibitor AVG inhibited the inducing effects of HRW on Rubisco and SBPase, further indicating that ETH may play important roles in the regulation of $\mathrm{H}_{2}$ during $\mathrm{H}_{2}$-induced adventitious root formation.

OEE1 has been suggested to be involved in photosynthesis and PS II activities (Yabuta et al. 2008). Chen et al. (2017) reported that OEE1 protein is necessary for oxygen evolving activity and is vital to maintain the stability of photosystem II. Sugihara et al. (2000) demonstrated that the level of OEE1 increased under $\mathrm{NaCl}$ treatment, and similar results were obtained at the transcription level. Fatehi et al. (2012) proposed that OEE1 was up-regulated in response to salinity, although in their study, $\mathrm{H}_{2}$ and ETH treatment down-regulated OEE1 expression. This was similar to the results of Bai et al. (2017) who reported that the protein levels of OEE1 in oat leaves decreased in response to salinity. The possible explanation for this discrepancy is that OEE1 may change under different transcription, translation or treatment.

Amino acid metabolism has been found to play an important role in plant protein synthesis, photosynthesis, and development (He et al. 2013). TDH, a key enzyme in amino acid metabolism, contribute to both carbon skeleton supply and ammonium assimilation in plants and also plays an important role in metabolic acclimation (Möckel et al. 1992). Our study suggests that $\mathrm{H}_{2}$ upregulated TDH expression and ETH inhibitor AVG suppress the inducing effects. Proteomic analysis showed higher levels of TDH accumulation in wild ginseng than in cultivated ginseng (Sun et al. 2016). Moreover, proteomic analysis of rice and wheat coleoptiles revealed the potential role of amino acid biosynthesis in cellular anoxia tolerance (Shingakiwells et al. 2011). Thus, $\mathrm{H}_{2}$ may increase carbon skeleton supply and metabolic acclimation in explants by enhancing TDH expression, which promotes adventitious root development. ETH is essential during this process. CAPX plays an essential role in the antioxidant defense mechanism (Wu et al. 2014) regulates plant growth, and induces organ formation (Zhang et al. 2013). The involvement of APX in fruit ripening and senescence has been proposed (Torres et al. 2003; Giribaldi et al. 2007), and Caverzan et al. (2012) demonstrated that APX genes can regulate both plant response to stresses and plant development. Additionally, APX mutant plant genes showed alterations in growth, physiology and antioxidant metabolism, suggesting the function of APX in plant development. Our results also show that CAPX expression was up-regulated by HRW or ethephon treatment, suggesting that $\mathrm{H}_{2}$ may increase the reduction of oxidative damage and increase the productivity of explants by enhancing CAPX expression. However, ETH inhibitor AVG depressed the promotive effects of HRW on CAPX. PDI, related to protein folding, modification and degradation, is a multifunctional protein in cells that assists many protein maturation processes (Wilkinson et al. 2004). It may catalyze protein thiol oxidation and restore and catalyze transformation disulfide bonds (Houston et al. 2005). PDI is also mainly associated with the protein secretory pathway in plants (Irsigler et al. 2007), and has been found to be down-regulated in rice under freezing stress (Hashimoto and Komatsu 2007) and in soybean 
379 leaves under drought stress (Irsigler et al. 2007). In our study, PDI was up-regulated under HRW

380 treatment and down-regulated under HRW+AVG treatment, suggesting that $\mathrm{H}_{2}$ may increase the 381 capacity of disulfide-bonded proteins by enhancing PDI expression. Meanwhile, ETH inhibitor

382 AVG reverses the inducing effects of HRW on PDI, indicating that ETH may play important

383 roles in $\mathrm{H}_{2}$-induced CAPX and PDI expression during rooting.

384

\section{Conclusion}

386 Our results show that both $\mathrm{H}_{2}$ and ETH play crucial roles in promoting adventitious root development. ETH might work as a downstream signaling molecule during $\mathrm{H}_{2}$-induced rooting. Further proteomic studies show that photosynthesis-related proteins (Rubisco and SBPase), amino and metabolism-related protein (TDH), stress response-related protein (CAPX), and folding, modification and degradation-related protein (PDI) may play positive roles in the ETH$\mathrm{H}_{2}$-induced adventitious rooting process. Oxygen-evolving enhancer protein (OEE1) may play inhibiting roles during that process. The mechanisms underlying adventitious root development are very complex and more research will need to be carried out to fully understand adventitious rooting signaling.

395

\section{Acknowledgments}

We thank Dr. Yongchao Zhu from Zhejiang University for providing guidance on experimental methods. We also thank Dr. Chen Bai from Gansu Academy of Agricultural Sciences for supplying a gas chromatographic analyzer. 
400

401

402

403

404

405

406

407

408

409

410

411

412

413

414

415

416

417

418

419

420

421

422

423

424

425

426

427

428

429

430

431

432

433

434

435

436

437

438

439

\section{References}

Andersson I (2008) Catalysis and regulation in Rubisco. $J$ Exp Bot. 59, 1555-1568. doi:10.1093/jxb/ern091

Bae KH, Choi YE, Shin CG, Kim YY, Kim YS (2006) Enhanced ginsenoside productivity by combination of ethephon and methyl jasmoante in ginseng (Panax ginseng CA Meyer) adventitious root cultures. Biotechnol Lett, 28(15), 1163-1166. doi:10.1007/s10529-0069071-1

Bai JH, Qin Y, Liu JH, Wang YQ, Sa R, Zhang N, Jia RN (2017) Proteomic response of oat leaves to long-term salinity stress. Environ Sci Pollut $R$. 24, 3387-3399. doi:10.1007/s11356-016-8092-0

Bai XG, Todd CD, Desikan R, Yang YP, Hu XY (2012) N-3-Oxo-Decanoyl-L-HomoserineLactone activates auxin-induced adventitious root formation via hydrogen peroxide- and nitric oxide-dependent cyclic GMP signaling in mung bean. Plant Physiol. 158, 725-736. doi: $10.1104 /$ pp.111.185769

Beyer EM (1976) A potent inhibitor of ethylene action in plants. Plant Physiol. 58, 268-271. doi: 10.1104/pp.58.3.268

Biondi S, Diaz T, Iglesias I, Gamberini G, Bagni N (1990) Polyamines and ethylene in relation to adventitious root formation in Prunus avium shoot cultures. Physiol plantarum, 78(3), 474-483. doi:10.1111/j.1399-3054.1990.tb09066.x

Cao Z, Duan X, Yao P, Cui W, Cheng D, Zhang J, Jin Q, Chen G, Dai T, Shen W (2017) Hydrogen gas is involved in auxin-induced lateral root formation by modulating nitric oxide synthesis. Int J Mol Sci, 18(10), 2084. doi:10.3390/ijms18102084

Caverzan A, Passaia G, Rosa SB, Ribeiro CW, Lazzarotto F, Margis-Pinheiro M (2012) Plant responses to stresses: role of ascorbate peroxidase in the antioxidant protection. Genet Mol Biol, 35(4), 1011-1019. doi:10.1590/S1415-47572012000600016

Chen Y, Wang M, Hu LL, Liao WB, Li CL (2017) Carbon monoxide is involved in hydrogen gas-induced adventitious root development in cucumber under simulated drought stress. Front Plant Sci. 8, 128. doi: 10.3389/fpls.2017.00128

Chen Z, Zhang GY, Yang MK, Li T, Ge F, Zhao JD (2017) Lysine acetylome analysis reveals photosystem II manganese-stabilizing protein acetylation is involved in negative regulation of oxygen evolution in model cyanobacterium synechococcus sp. PCC 7002. Mol Cell Proteomics. 16, 1297-1311. doi: 10.1074/mcp.M117.067835

Clark DG, Gubrium EK, Barrett JE, Nell TA, Klee HJ (1999) Root formation in ethyleneinsensitive plants. Plant Physiol, 121(1), 53-60. doi:10.1104/pp.121.1.53

Cui DZ, Wu DD, Liu J, Li DT, Xu CY, Li S, Li P, Zhang H, Liu X, Jiang C, Wang LW, Chen TT, Chen HB, Zhao L (2015) Proteomic analysis of seedling roots of two maize inbred lines that differ significantly in the salt stress response. Plos One 10, e0116697. doi: 10.1371/journal.pone.0116697

Cui WT, Qi F, Zhang YH, Cao H, Zhang J, Wang R, Shen WB (2015) Methane-rich water induces cucumber adventitious rooting through heme oxygenase1/carbon monoxide and 
440

441

442

443

444

445

446

447

448

449

450

451

452

453

454

455

456

457

458

459

460

461

462

463

464

465

466

467

468

469

470

471

472

473

474

475

476

477

478

479

480

$\mathrm{Ca}^{2+}$ pathways. Plant Cell Rep. 34, 435-445. doi: 10.1007/s00299-014-1723-3

Damerval C, Vienne DD, Zivy M, Thiellement H (1986) Technical improvements in twodimensional electrophoresis increase the level of genetic variation detected in wheatseedling proteins. Electrophoresis 7, 52-54. doi: 10.1002/elps.1150070108

Fatehi F, Hosseinzadeh A, Alizadeh H, Brimavandi T, Struik PC (2012) The proteome response of salt-resistant and salt-sensitive barley genotypes to long-term salinity stress. Mol Biol Rep. 39, 6387-6397. doi: 10.1007/s11033-012-1460-z

Giribaldi M, Perugini I, Sauvage FX, Schubert A (2007) Analysis of protein changes during grape berry ripening by 2-DE and MALDI-TOF. Proteomics 7, 3154-3170. doi: 10.1002/pmic.200600974

Gunn LH, Valegard K, Andersson I (2017) A unique structural domain in Methanococcoides burtonii ribulose-1, 5-bisphosphate carboxylase/oxygenase (Rubisco) acts as a small subunit mimic. J Biol Chem. 292, 6838-6850. doi: 10.1074/jbc.M116.767145

Hashimoto M, Komatsu S (2007) Proteomic analysis of rice seedlings during cold stress. Proteomics 7, 1293-1302. doi: 10.1002/pmic.200600921

He Y, Dai SJ, Zhu N, Pang QY, Chen SX (2013) Integrated proteomics and metabolomics of Arabidopsis acclimation to gene-dosage dependent perturbation of isopropylmalate dehydrogenases. Plos One 8, e57118. doi: 10.1371/journal.pone.0057118

Hong Y, Chen S, Zhang JM (2010) Hydrogen as a selective antioxidant: a review of clinical and experimental studies. $J$ Int Med Res. 38, 1893-1903. doi: 10.1177/147323001003800602

Houston NL, Fan C, Xiang JQ, Schulze JM, Jung R, Boston RS (2005) Phylogenetic analyses identify 10 classes of the protein disulfide isomerase family in plants, including singledomain protein disulfide isomerase-related proteins. Plant Physiol. 137, 762-778. doi: $10.2307 / 4629717$

Hu HL, Li PX, Wang YN, Gu RX (2014) Hydrogen-rich water delays postharvest ripening and senescence of kiwifruit. Food Chem. 156, 100-109. doi: 10.1016/j.foodchem.2014.01.067

Ichikawa Y, Tamoi M, Sakuyama H, Maruta T, Ashida H (2012) Generation of transplastomic lettuce with enhanced growth and high yield. Food Chem. 1, 322-326. doi: 10.4161/gmcr.1.5.14706

Irsigler AS, Costa MD, Zhang P, Reis PA, Boston RS, Fontes EP (2007) Expression profiling on soybean leaves reveals integration of ER- and osmotic-stress pathways. BMC Genomics 8, 431. doi: 10.1186/1471-2164-8-431

Jin Q, Zhu K, Cui W, Xie Y, Han B, Shen WB (2013) Hydrogen gas acts as a novel bioactive molecule in enhancing plant tolerance to paraquat-induced oxidative stress via the modulation of heme oxygenase-1 signalling system. Plant Cell Environ. 36, 956-969. doi: 10.1111/pce.12029

Jin X, Liao WB, Yu JH, Ren PJ, Mohammed MD, Wang M, Niu LJ, Li XP, Xu XT (2017) Nitric oxide is involved in ethylene-induced adventitious rooting in marigold (Tagetes erecta $\mathrm{L}$.). $J$ Hortic Sci Biotech. 97, 620-631. doi: 10.1139/CJPS-2016-0156

Khan NA, Khan MIR, Ferrante A, Poor P (2017) Editorial: Ethylene: A Key Regulatory Molecule in Plants. Plant Physiol. 8, 1728. doi: 10.3389/fpls.2017.01782 
481

482

483

484

485

486

487

488

489

490

491

492

493

494

495

496

497

498

499

500

501

502

503

504

505

506

507

508

509

510

511

512

513

514

515

516

517

518

519

520

521

Liao WB, Zhang ML, Huang GB, Yu JH (2012) $\mathrm{Ca}^{2+}$ and $\mathrm{CaM}$ are involved in NO- and $\mathrm{H}_{2} \mathrm{O}_{2}$ induced adventitious root development in marigold. J Plant Growth Regul. 31, 253-264. doi: 10.1007/s00344-011-9235-7

Lin YT, Li MY, Cui W, Lu W, Shen WB (2012) Haem oxygenase-1 is involved in hydrogen sulfide-induced cucumber adventitious root formation. J Plant Growth Regul. 31, 519-528. doi: 10.1007/s00344-012-9262-z

Lin YT, Zhang W, Qi F, Cui YT, Xie YJ, Shen WB (2014) Hydrogen-rich water regulates cucumber adventitious root development in a heme oxygenase-1/carbon monoxidedependent manner. J Plant Physiol. 17, 11-8. doi: 10.1016/j.jplph.2013.08.009

Liu J, Mukherjee L, Reid DM (1990) Adventitious rooting in hypocotyls of sunflower (Helianthus annuus) seedlings. III. The role of ethylene. Physiol Plantarum, 78(2), 268-276. doi:10.1111/j.1399-3054.1990.tb02091.x

Liu JH, Mukhcrjee I, Reid DM (1990) Adventitious rooting in hypocotyls of sunflower (Helianthus annuus) seedling. Ш. The role of ethylene. Physiol Plantarum 78, 268-276. doi: 10.1111/j.1399-3054.1990.tb02091.x

Ma JH, Yao JL, Cohen D, Morris B (1998) Ethylene inhibitors enhance in vitro root formation from apple shoot cultures. Plant Cell Rep, 17(3), 211-214. doi:10.1007/s002990050380

Möckel B, Eggeling L, Sahm H (1992) Functional and structural analyses of threonine dehydratase from Corynebacterium glutamicum. J Bacteriol. 174(24), 8065-8072. doi: 10.1128/jb.174.24.8065-8072.1992

Ogawa T, Tamoi M, Kimura A, Mine A, Sakuyama H, Yoshida E, Maruta T, Suzuki K, Ishikawa T, Shigeoka S (2015) Enhancement of photosynthetic capacity in Euglena gracilis by expression of cyanobacterial fructose-1,6-/sedoheptulose-1,7-bisphosphatase leads to increases in biomass and wax ester production. Biotechnol Biofuels. 8, 1-11. doi:10.1186/s13068-015-0264-5

Ohsawa I, Ishikawa M, Takahashi K Watanabe M, Nishimaki K, Yamagata K, Katsura K, Katayama Y, Asoh S, Ohta S (2007) Hydrogen acts as a therapeutic antioxidant by selectively reducing cytotoxic oxygen radicals. Nat Med. 13, 688-694. doi: 10.1038/nm1577

Pan R, Wang JX, Tian XS (2002) Influence of ethylene on adventitious root formation in mung bean hypocotyl cuttings. Plant Growth Regul. 36(2), 135-139. doi.org/10.1023/A:1015051725089

Pitts RJ, Cernac A, Estelle M (1998) Auxin and ethylene promote root hair elongation in Arabidopsis. Plant J, 16(5), 553-560. doi:10.1046/j.1365-313x.1998.00321.x

Riov J, Yang SF (1989) Ethylene and auxin-ethylene interaction in adventitious root formation in mung bean (Vigna radiata) cuttings. J Plant Growth Regul, 8(2), 131. doi:10.1007/BF02025280

Shingakiwells RN, Huang S, Taylor NL, Carroll AJ, Zhou W, Millar AH (2011) Differential molecular responses of rice and wheat coleoptiles to anoxia reveal novel metabolic adaptations in amino acid metabolism for tissue tolerance. Plant Physiol. 156, 1706-1724. doi: 10.4161/psb.6.10.17107

Shinohara T, Martin EA, Leskovar DI (2017) Ethylene regulators influence germination and root 
522

523

524

525

526

527

528

529

530

531

532

533

534

535

536

537

538

539

540

541

542

543

544

545

546

547

548

549

550

551

552

553

554

555

556

557

558

559

560

growth of globe artichoke seedlings exposed to heat stress conditions. Seed Sci Technol, 45(1), 167-178. doi:10.15258/sst.2017.45.1.07

Simkin AJ, Lopez-Calcagno PE, Davey PA, Headland LR, Lawson T (2017) Simultaneous stimulation of the SBPase, FBP aldolase and the photorespiratory GDC-H protein increases $\mathrm{CO}_{2}$ assimilation, vegetative biomass and seed yield in Arabidopsis. Plant Biotechnol J. 15, 805-816. doi: 10.1111/pbi.12676

Su NN, Wu Q, Liu YY, Cai JT, Shen WB, Xia K, Cui J (2014) Hydrogen-rich water reestablishes ROS homeostasis but exerts differential effects on anthocyanin synthesis in two varieties of radish sprouts under uv-a irradiation. $J$ Agr Food Chem. 62, 6454-6462. doi: $10.1021 / \mathrm{jf5019593}$

Sugihara K, Hanagata N, Dubinsky Z, Baba S, Karube I (2000) Molecular characterization of cDNA encoding oxygen evolving enhancer protein 1 increased by salt treatment in the mangrove Bruguiera gymnorrhiza. Plant and cell physiol, 41(11), 1279-1285. doi:10.1093/pcp/pcd061

Sun H, Liu FB, Sun LW, Liu JZ, Wang MY, Chen XN, Xu XH, Ma R, Feng K, Jiang R (2016) Proteomic analysis of differences in amino acid metabolism between wild and cultivated Panax ginseng. J Ginseng Res. 40, 113-120. doi: 10.1016/j.jgr.2015.06.001

Torres R, Valentines MC, Usall J, Viñas I, Larrigaudiere C (2003) Possible involvement of hydrogen peroxide in the development of resistance mechanisms in 'Golden Delicious' apple fruit. Postharvest Biol Tec. 27, 235-242. doi: 10.1016/S0925-5214(02)00110-2

Wang J, Pan R (2006) Effect of ethylene on adventitious root formation. In Ethylene Action in Plants (pp. 69-79). Springer, Berlin, Heidelberg. doi: 10.1007/978-3-540-32846-9_4

Wilkinson B, Gilbert HF (2004) Protein disulfide isomerase. BBA-Proteins Proteom. 1669,5-44. doi: 10.1016/j.bbapap.2004.02.017

Wu GX, Wang G, Ji J, Gao HL, Guan WZ, Wu J, Guan CF, Wang YR (2014) Cloning of a cytosolic ascorbate peroxidase gene from Lycium chinense Mill and enhanced salt tolerance by overexpressing in tobacco. Gene 543, 85-92. doi: 10.1016/j.gene.2014.03.061

Wu Q, Su, NN, Cai JT, Shen ZG, Cui J (2015) Hydrogen-rich water enhances cadmium tolerance in Chinese cabbage by reducing cadmium uptake and increasing antioxidant capacities. J Plant Physiol. 175, 174-182. doi: 10.1016/j.jplph.2014.09.017

Xie YJ, Mao Y, Zhang W, Lai DW, Wang Q, Shen, WB (2014) Reactive Oxygen speciesdependent nitric oxide production contributes to hydrogen-promoted stomatal closure in Arabidopsis. Plant Physiol. 165, 759-773. doi: 10.1104/pp.114.237925

Xu DQ, Gifford RM, Chow WS (1994) Photosynthetic acclimation in pea and soybean to high atmospheric $\mathrm{CO}_{2}$ partial pressure. Plant Physiol. 106, 661-671. doi:10.1104/pp.106.2.643

Xu XT, Jin X, Liao WB, Mohammed MD, Li XP, Wang M, Niu LJ, Ren PJ, Zhu YC (2017) Nitric oxide is involved in ethylene-induced adventitious root development in cucumber (Cucumis sativus L.) explants. Sci Hortic-Amsterdam. 215, 65-71. doi.org/10.1016/j.scienta.2016.12.006 
561

562

563

564

565

566

567

568

569

570

571

572

573

574

575

576

577

578

579

580

581

582

583

584

585

586

Xu XW, Ji J, Ma XT, Xu Q, Qi XH, Chen XH (2016) Cloning and expression analysis of Cucumis sativus calcium-dependent protein kinase 5 gene (CsCDPK5) under waterlogging stress. Acta Hortic. 43, 704-714. Doi:10.16420/j.issn.0513-353x.2015-0851

Xuan W. Zhu FY, Xu S, Huang BK, Ling TF, Qi JY, Ye MB, Shen WB (2008) The heme oxygenase/carbon monoxide system is involved in the auxin-induced cucumber adventitious rooting process. Plant Physiol. 148, 881-893.doi:10.1104/pp.108.125567

Yabuta Y, Tamoi M, Yamamoto K, Tomizawa K, Yokota A, Shigeoka S (2008) Molecular designing of photosynthesis-elevated chloroplasts for mass accumulation of a foreign protein. Plant Cell Physiol. 49, 375-385. doi: 10.1093/pcp/pcn014

Zeng JQ, Ye ZH, Su XJ (2014) Progress in the study of biological effects of hydrogen on higher plants and its promising application in agriculture. Med Gas Res. 4, 15. doi: 10.1186/20459912-4-15

Zhang D, Ren L, Yue JH, Wang L, Zhuo LH, Hen XH (2013) A comprehensive analysis of flowering transition in Agapanthus praecox ssp. orientalis (Leighton) Leighton by using transcriptomic and proteomic techniques. $J$ Proteomics. 80, 1-25. doi: 10.1016/j.jprot.2012.12.028

Zhang S, Zhang LL, Zhou QY (2015) Comparative proteomic analysis of tetraploid black locust (Robinia pseudoacacia L.) cuttings in different phases of adventitious root development. Trees. 29, 367-38. doi: 10.1007/s00468-014-1116-9

Zhu YC, Liao WB (2017) The metabolic constituent and rooting-related enzymes responses of marigold explants to hydrogen gas during adventitious root development. Theor Exp Plant Phys. 29, 77-85. doi: 10.1007/s40626-017-0085-y

Zhu YC, Liao WB, Niu LJ, Wang M (2016) Nitric oxide is involved in hydrogen gas-induced cell cycle activation during adventitious root formation in cucumber. BMC Plant Biol. 16, 146. doi: 10.1186/s12870-016-0834-0

Peer] reviewing PDF | (2019:07:39221:3:0:NEW 4 Mar 2020) 


\section{Table 1 (on next page)}

List of the genes whose transcription profile was evaluated by RT-PCR 
2 Table 1 List of the genes whose transcription profile was evaluated by RT-PCR

\begin{tabular}{|c|c|c|c|}
\hline Gene name & NCBI accession number & primer & $5^{\prime}-3$ ' primer sequence \\
\hline \multirow[t]{2}{*}{ CsACS3 } & \multirow{2}{*}{$\mathrm{AB} 006805.1$} & $\mathrm{~F}$ & 5'-CCTTGCAGAGGCTGGCGATG-3' \\
\hline & & $\mathrm{R}$ & 5'-GGTGACTTGGAAGCCGTTGGAG-3' \\
\hline \multirow[t]{2}{*}{$\mathrm{CsACO} 1$} & \multirow{2}{*}{ AB006806.1 } & $\mathrm{F}$ & 5'-AGGTAGGTGGCCTGCAACTCC-3' \\
\hline & & $\mathrm{R}$ & 5'-CTCCGAGGTTGACGACAATGGC-3' \\
\hline \multirow[t]{2}{*}{ Rubisco } & \multirow[t]{2}{*}{ NP_198657.1 } & $\mathrm{F}$ & 5'-GAGATTGAGGAGGCTAAGAAGGAA-3' \\
\hline & & $\mathrm{R}$ & 5'-GGGCTTGTAGGCGATGAAAC -3' \\
\hline \multirow[t]{2}{*}{ SBPase } & \multirow[t]{2}{*}{ NP_001267658.1 } & $\mathrm{F}$ & 5'-GAGTTCGTTATTTGGGGAGTCATT -3' \\
\hline & & $\mathrm{R}$ & 5'-TTATCAGGGGTTGCTTTGGTG -3' \\
\hline \multirow[t]{2}{*}{$\mathrm{TDH}$} & \multirow[t]{2}{*}{ XM_004143321.2 } & $\mathrm{F}$ & 5'-CCATTCAACTTTCCAACAGAACC -3' \\
\hline & & $\mathrm{R}$ & 5'- CGAGCCATCAACAACAGCA-3' \\
\hline \multirow[t]{2}{*}{ CAPX } & \multirow[t]{2}{*}{ NM_001280706 } & $\mathrm{F}$ & 5'-TTGGCTGGTGTTGTTGCTGT -3' \\
\hline & & $\mathrm{R}$ & 5'-GGCTCGGGTTTGTCCTCTCT -3' \\
\hline \multirow[t]{2}{*}{ PDI } & \multirow[t]{2}{*}{ XM_004149750.2 } & $\mathrm{F}$ & 5'- TGAGTTTTACGCCCCTTGGT-3' \\
\hline & & $\mathrm{R}$ & 5'-TCTCTGTTTGACTCCTCGTTGG -3' \\
\hline \multirow[t]{2}{*}{ OEE1 } & \multirow[t]{2}{*}{ XM-004141898.2 } & $\mathrm{F}$ & 5'-TTTGAAGTTGGTGCTGATGGTT-3' \\
\hline & & $\mathrm{R}$ & 5'- GGTGAAGAGGAACGGGACA-3 \\
\hline \multirow{2}{*}{ Actin } & \multirow{2}{*}{ DQ115883.1 } & $\mathrm{F}$ & 5'-TGGACTCTGGTGATGGTGTTA-3' \\
\hline & & $\mathrm{R}$ & 5'-CAATGAGGGATGGCTGGAAAA-3' \\
\hline
\end{tabular}

3

4 


\section{Table 2 (on next page)}

Identification and analysis of proteins differentially expressed in response to ETH inhibitor on $\mathrm{H}_{2}$-induced adventitious root development in cucumber explants 
1 .Table 2 Identification and analysis of proteins differentially expressed in response to ETH 2 inhibitor on $\mathrm{H}_{2}$-induced adventitious root development in cucumber explants

\begin{tabular}{|c|c|c|c|c|c|c|c|c|}
\hline Spot No. ${ }^{\mathrm{a}}$ & Identified protein ${ }^{b}$ & Species & Score $^{\mathrm{c}}$ & $\begin{array}{c}\text { NCBI accession } \\
\text { Number }\end{array}$ & $\mathbf{M W}^{\mathrm{d}}$ & $\mathbf{P i}^{\mathrm{e}}$ & $\begin{array}{l}\text { Peptides } \\
\text { Count }^{\mathrm{f}}\end{array}$ & Up/Down ${ }^{g}$ \\
\hline K9/1628 & $\begin{array}{l}\text { Glutamine synthetase } \\
\text { ribulose bisphosphate }\end{array}$ & Cucumis sativus & 406 & KGN57792.1 & 39251.8 & 5.82 & 13 & $\downarrow$ \\
\hline K10/2129 & $\begin{array}{c}\text { carboxylase/oxygenase precursor } \\
\text { peptide }\end{array}$ & Cucumis sativus & 78 & AAA33131.1 & 21049.4 & 7.55 & 12 & $\uparrow$ \\
\hline K11/1937 & Unknow protein & Cucumis sativus & 234 & KGN44928.1 & 22556.6 & 4.45 & 13 & $\downarrow$ \\
\hline K12/1908 & Cytosolic ascorbate peroxidase & Cucumis sativus & 595 & KGN65655.1 & 27377.8 & 5.43 & 17 & $\uparrow$ \\
\hline K13/1561 & $\begin{array}{l}\text { Sedoheptulose-1,7- } \\
\text { bisphosphatase }\end{array}$ & Cucumis sativus & 534 & KGN50632.1 & 42075.4 & 5.96 & 22 & $\uparrow$ \\
\hline K14/1799 & $\begin{array}{l}\text { Eukaryotic translation elongation } \\
\text { factor } 1 \text { delta isoform } \mathrm{X} 1\end{array}$ & Cucumis sativus & 417 & XP_011652060.1 & 24670.3 & 4.45 & 15 & $\downarrow$ \\
\hline K15/1817 & $\begin{array}{l}\text { Oxygen-evolving enhancer } \\
\text { protein } 1\end{array}$ & Cucumis sativus & 905 & KGN48464.1 & 34938.8 & 6.24 & 24 & $\downarrow$ \\
\hline K16/2139 & $\begin{array}{l}\text { PREDICTED:11S globulin seed } \\
\text { storage protein 2-like }\end{array}$ & Cucumis sativus & 458 & XP_011652795.1 & 54382 & 5.71 & 11 & $\downarrow$ \\
\hline K17/2062 & $\begin{array}{c}\text { Cytochrome b6-f complex iron- } \\
\text { sulfur subunit }\end{array}$ & Cucumis sativus & 112 & KGN43571.1 & 24255.2 & 8.45 & 9 & $\downarrow$ \\
\hline K18/1169 & Chloroplast transketolase & Cucumis sativus & 712 & KGN56609.1 & 80569.6 & 6 & 27 & $\downarrow$ \\
\hline K19/2156 & $\begin{array}{l}\text { Ribulose bisphosphate } \\
\text { carboxylase small chain }\end{array}$ & Cucumis sativus & 68 & KGN52085.1 & 20685.2 & 8.24 & 11 & $\downarrow$ \\
\hline K20/1284 & $\begin{array}{l}\text { ATPase alpha subunit } \\
\text { (chloroplast) }\end{array}$ & Cucumis sativus & 385 & AAZ94637.1 & 55348 & 5.13 & 24 & $\uparrow$ \\
\hline K21/2064 & $\begin{array}{l}\text { ATPase alpha subunit } \\
\text { (chloroplast) }\end{array}$ & Cucumis sativus & 246 & AAZ94637.1 & 55348 & 5.13 & 20 & $\downarrow$ \\
\hline $\mathrm{K} 22 / 361$ & $\begin{array}{l}\text { 26S protease regulatory subunit } \\
\qquad 6 \mathrm{~A} \text { homolog }\end{array}$ & Cucumis sativus & 230 & XP_004135596.1 & 38614.9 & 5.16 & 21 & $\downarrow$ \\
\hline $\mathrm{K} 23 / 748$ & $\begin{array}{c}\text { Oxygen-evolving enhancer } \\
\text { protein } 1\end{array}$ & Cucumis sativus & 752 & KGN48464.1 & 34938.8 & 6.24 & 20 & $\downarrow$ \\
\hline $\mathrm{K} 24 / 533$ & Mg-protoporphyrin IX chelatase & Cucumis sativus & 236 & KGN49283.1 & 45728 & 5.72 & 20 & $\downarrow$ \\
\hline $\mathbf{L} 1 / 203$ & Protein disulfide-isomerase & Cucumis sativus & 83 & KGN47715.1 & 57045.6 & 4.88 & 12 & $\uparrow$ \\
\hline $\mathbf{L} 2 / 230$ & Threonine dehydratase & Cucumis sativus & 620 & KGN48214.1 & 67198.9 & 6.22 & 25 & $\uparrow$ \\
\hline L3/1196 & $\begin{array}{l}\text { PSII reaction center subunit V } \\
\text { (chloroplast) }\end{array}$ & Cucumis sativus & 103 & AAZ94668.1 & 9380.7 & 4.83 & 4 & $\downarrow$ \\
\hline $\mathbf{L 4 / 8 5 8}$ & Cytosolic ascorbate peroxidase & Cucumis sativus & 716 & KGN65655.1 & 27377.8 & 5.43 & 15 & $\uparrow$ \\
\hline L6/656 & Proteasome subunit alpha type & Cucumis sativus & 466 & KGN62618.1 & 30861.4 & 4.98 & 9 & $\downarrow$ \\
\hline L7/1009 & Unknow & Cucumis sativus & 412 & KGN57117.1 & 18646.5 & 4.56 & 9 & $\downarrow$ \\
\hline $\mathbf{L 8} / \mathbf{1 5 8}$ & Malic enzyme & Cucumis sativus & 496 & KGN66170.1 & 65093.8 & 5.72 & 23 & $\uparrow$ \\
\hline L9/975 & Chlorophyll a-b binding protein, & Cucumis sativus & 270 & KGN51208.1 & 26517.6 & 5.84 & 7 & $\uparrow$ \\
\hline
\end{tabular}




\begin{tabular}{|c|c|c|c|c|c|c|c|c|}
\hline & chloroplastic & & & & & & & \\
\hline L10/1116 & $60 \mathrm{~S}$ acidic ribosomal protein $\mathrm{P} 1$ & Cucumis sativus & 355 & KGN56349.1 & 11414.7 & 4.34 & 3 & $\uparrow$ \\
\hline L11/747 & Cysteine protease & Cucumis sativus & 114 & KGN62647.1 & 40614.9 & 5.2 & 8 & $\downarrow$ \\
\hline L12/200 & Protein disulfide-isomerase & Cucumis sativus & 90 & KGN47715.1 & 57045.6 & 4.88 & 18 & $\downarrow$ \\
\hline L13/527 & Mg-protoporphyrin IX chelatase & Cucumis sativus & 200 & KGN49283.1 & 45728 & 5.72 & 19 & $\downarrow$ \\
\hline L14/1132 & $\begin{array}{l}\text { Ribulose bisphosphate } \\
\text { carboxylase small chain }\end{array}$ & Cucumis sativus & 100 & KGN52085.1 & 20685.2 & 8.24 & 11 & $\uparrow$ \\
\hline L15/502 & Unknow & Cucumis sativus & 312 & KGN57401.1 & 31417.5 & 4.82 & 5 & $\downarrow$ \\
\hline L16/626 & $\begin{array}{c}\text { Sedoheptulose-1,7- } \\
\text { bisphosphatase }\end{array}$ & Cucumis sativus & 546 & KGN50632.1 & 42075.4 & 5.96 & 18 & $\uparrow$ \\
\hline L17/896 & $\begin{array}{l}\text { PREDICTED: } 29 \mathrm{kDa} \\
\text { ribonucleoprotein, chloroplastic }\end{array}$ & Cucumis sativus & 298 & XP_004137828.1 & 30479.5 & 5.84 & 7 & $\downarrow$ \\
\hline L18/103 & Chloroplast HSP70 & Cucumis sativus & 412 & KGN61439.1 & 75350 & 5.18 & 25 & $\downarrow$ \\
\hline L19/447 & $\begin{array}{l}\text { 30S ribosomal protein } \mathrm{S} 1, \\
\text { chloroplastic }\end{array}$ & Cucumis sativus & 496 & XP_004147619.1 & 45304.5 & 5.34 & 18 & $\downarrow$ \\
\hline L20/1129 & $\begin{array}{l}\text { PREDICTED: 60S acidic } \\
\text { ribosomal protein P2-4 }\end{array}$ & Cucumis sativus & 93 & XP_004150488.1 & 11419.9 & 4.53 & 8 & $\downarrow$ \\
\hline L21/982 & $\begin{array}{l}\text { PREDICTED: 11S globulin } \\
\text { subunit beta }\end{array}$ & Cucumis sativus & 479 & XP_011651441.1 & 57575.8 & 7.21 & 15 & $\downarrow$ \\
\hline $\mathrm{L} 22 / 1140$ & $\begin{array}{l}\text { ribulose-1,5-bisphosphate } \\
\text { carboxylase small subunit }\end{array}$ & Cucumis sativus & 113 & CCF55356.1 & 20713.2 & 8.24 & 15 & $\uparrow$ \\
\hline $\mathbf{L} 23 / 732$ & $\begin{array}{l}\text { PREDICTED: } 14-3-3 \text {-like } \\
\text { protein D }\end{array}$ & Cucumis sativus & 120 & XP_004136830.1 & 29379.5 & 4.76 & 10 & $\downarrow$ \\
\hline M15/139 & $\begin{array}{c}\text { PREDICTED: ruBisCO large } \\
\text { subunit-binding protein subunit } \\
\text { alpha }\end{array}$ & Cucumis sativus & 401 & XP_004145754.1 & 61399.9 & 5.06 & 26 & $\downarrow$ \\
\hline M17/239 & $\begin{array}{c}\text { Oxygen-evolving enhancer } \\
\text { protein } 1\end{array}$ & Cucumis sativus & 216 & KGN48464.1 & 34938.8 & 6.24 & 19 & \\
\hline M18/1018 & $\begin{array}{l}\text { PREDICTED: } 60 \mathrm{~S} \text { acidic } \\
\text { ribosomal protein } \mathrm{P} 1\end{array}$ & Cucumis sativus & 170 & KGN56349.1 & 11414.7 & 4.34 & 2 & $\downarrow$ \\
\hline M19/1030 & Cytosolic ascorbate peroxidase & Cucumis sativus & 407 & KGN65655.1 & 27377.8 & 5.43 & 17 & $\downarrow$ \\
\hline M20/340 & $\begin{array}{l}\text { ribulose-1,5-bisphosphate } \\
\text { carboxylase small subunit }\end{array}$ & Cucumis sativus & 137 & CCF55356.1 & 20713.2 & 8.24 & 14 & $\downarrow$ \\
\hline M21/162 & Threonine dehydratase & Cucumis sativus & 206 & KGN48214.1 & 67198.9 & 6.22 & 22 & $\downarrow$ \\
\hline $\mathrm{M23} / 462$ & $\begin{array}{c}\text { Sedoheptulose-1,7- } \\
\text { bisphosphatase }\end{array}$ & Cucumis sativus & 250 & KGN50632.1 & 42075.4 & 5.96 & 18 & $\downarrow$ \\
\hline M24/354 & Beta-form rubisco activase & Cucumis sativus & 241 & KGN50568.1 & 48292.6 & 8.19 & 19 & $\downarrow$ \\
\hline $\mathbf{N} 1 / 351$ & Unknow & Cucumis sativus & 238 & KGN59544.1 & 36680 & 4.7 & 23 & $\downarrow$ \\
\hline $\mathbf{N 2 / 1 1 7}$ & Protein disulfide-isomerase & Cucumis sativus & 62 & KGN47715.1 & 57045.6 & 4.88 & 16 & $\downarrow$ \\
\hline
\end{tabular}

3 Spots K9/1628 to K21/2064 were the proteins in ETH treatment; K22/361 to L23/732 were the proteins in ETH treatment and the 4 control; M15/139 to N2/117 were the proteins in HRW+AVG treatment. 
$5 \quad$ a Spot numbers are arbitrary as assigned by the software of PD-Quest 8.0.

$6 \mathrm{~b}^{\mathrm{b}}$ The name and functional categories of the proteins using MALDI TOF-TOF MS.

$7 \mathrm{c}^{\mathrm{c}}$ The Mascot score obtained after searching against the NCBI nr database.

$8 \mathrm{~d}, \mathrm{e}$ Theoretical molecular mass (MV) and isoelectric point (PI) of the identified protein.

9 f Number of peptides sequenced.

$10 \mathrm{~g}$ “ $\uparrow$ ” represents up-regulated expression, “ $\downarrow$ ” represents down-regulated expression. 


\section{Table 3 (on next page)}

Analysis of differential protein expression during $\mathrm{H}_{2}$, ETH and AVG-induced adventitious root development 
2 Table 3 Analysis of differential protein expression during $\mathrm{H}_{2}$, ETH and AVG-induced adventitious

3 root development

\begin{tabular}{|c|c|c|c|c|c|}
\hline Protein name & Functional category & Control & $\mathbf{H}_{2}$ & ETH & $\mathrm{H}_{2}+\mathrm{AVG}$ \\
\hline $\begin{array}{l}\text { ribulose-1,5-bisphosphate } \\
\text { carboxylase small subunit }\end{array}$ & Photosynthesis & - & $\uparrow$ & $\uparrow$ & $\downarrow$ \\
\hline $\begin{array}{l}\text { Sedoheptulose-1,7- } \\
\text { bisphosphatase }\end{array}$ & photosynthesis & - & $\uparrow$ & $\uparrow$ & $\downarrow$ \\
\hline Threonine dehydratase & amino and metabolism & - & $\uparrow$ & - & $\downarrow$ \\
\hline Cytosolic ascorbate peroxidase & stress response & - & $\uparrow$ & $\uparrow$ & $\downarrow$ \\
\hline Protein disulfide-isomerase & $\begin{array}{l}\text { Protein folding, modification and } \\
\text { degradation }\end{array}$ & - & $\uparrow$ & - & $\downarrow$ \\
\hline $\begin{array}{l}\text { Oxygen-evolving enhancer } \\
\text { protein } 1\end{array}$ & photosynthesis & - & $\downarrow$ & $\downarrow$ & $\uparrow$ \\
\hline
\end{tabular}

4 “ ” represents up-regulated expression, “ $\downarrow$ " represents down-regulated expression. 


\section{Figure 1}

Effects of different concentrations of HRW on adventitious root development.

The primary root system was removed from hypocotyls of 7-day-old germinated cucumber. Explants were incubated with distilled water or different concentrations of HRW and indicated for 7 days. The number $(\mathbf{A})$ of adventitious roots per explant were expressed as mean $\pm \mathrm{SE}$ ( $n=20$ explants from each of four independent experiments). Bars with different lowercase letters were significantly different (Duncan's multiple range test, $P<0.05$. Photographs (B-F) show hypocotyl explants after 7 days of the treatments indicated.

$\mathbf{A}$

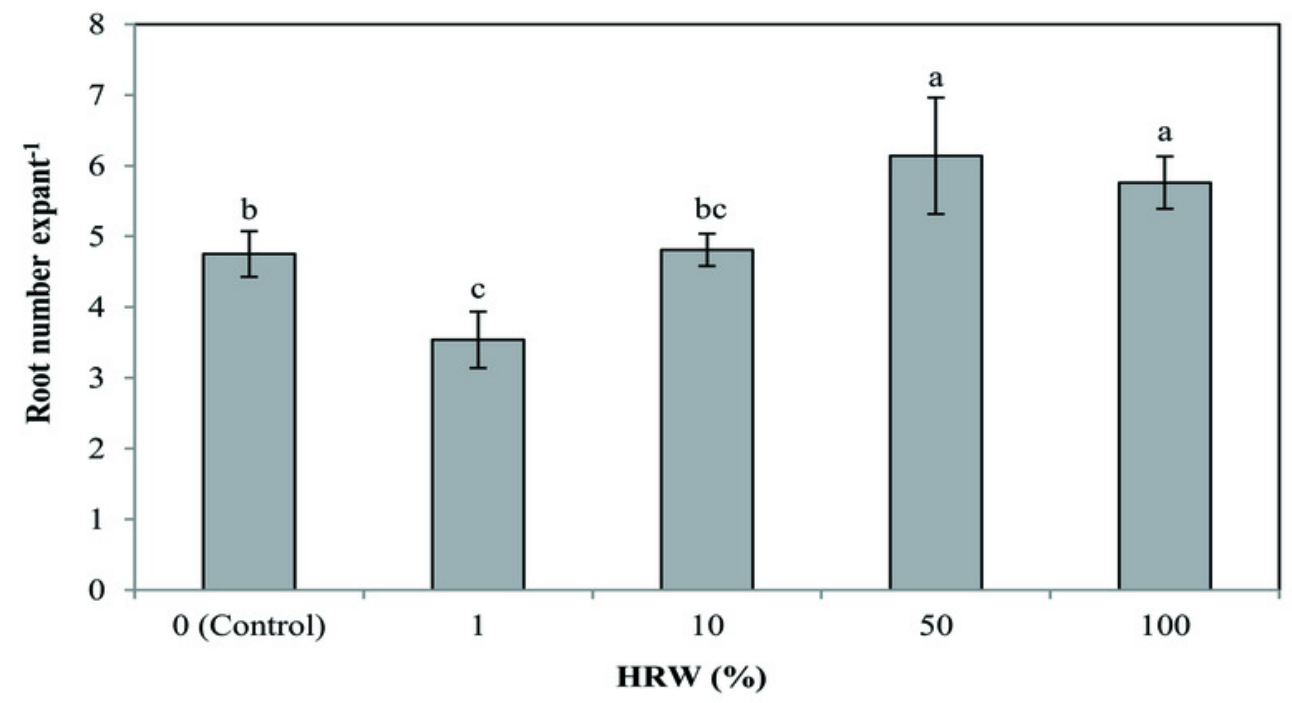

B

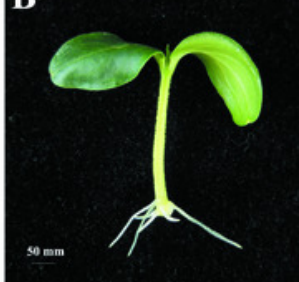

C

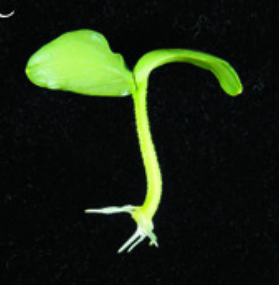

0 (Control)

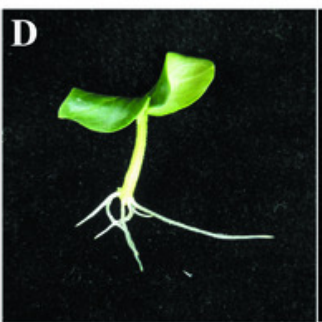

10
E

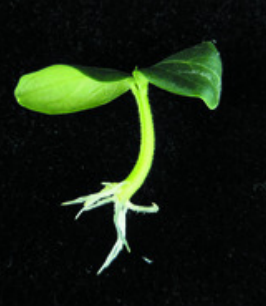

50

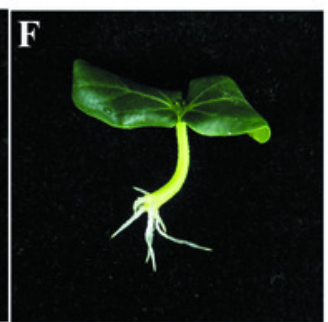

100 


\section{Figure 2}

Effects of different concentrations of ethephon on adventitious root development.

The primary root system was removed from hypocotyls of 7-day-old germinated cucumber. Explants were incubated with distilled water or different concentrations of ethephon and indicated for 7 days. The number (A) of adventitious roots per explant were expressed as mean $\pm S E$ ( $n=20$ explants from each of four independent experiments). Bars with different lowercase letters were significantly different (Duncan's multiple range test, $P<0.05$. Photographs (B-G) show hypocotyl explants after 7 days of the treatments indicated.

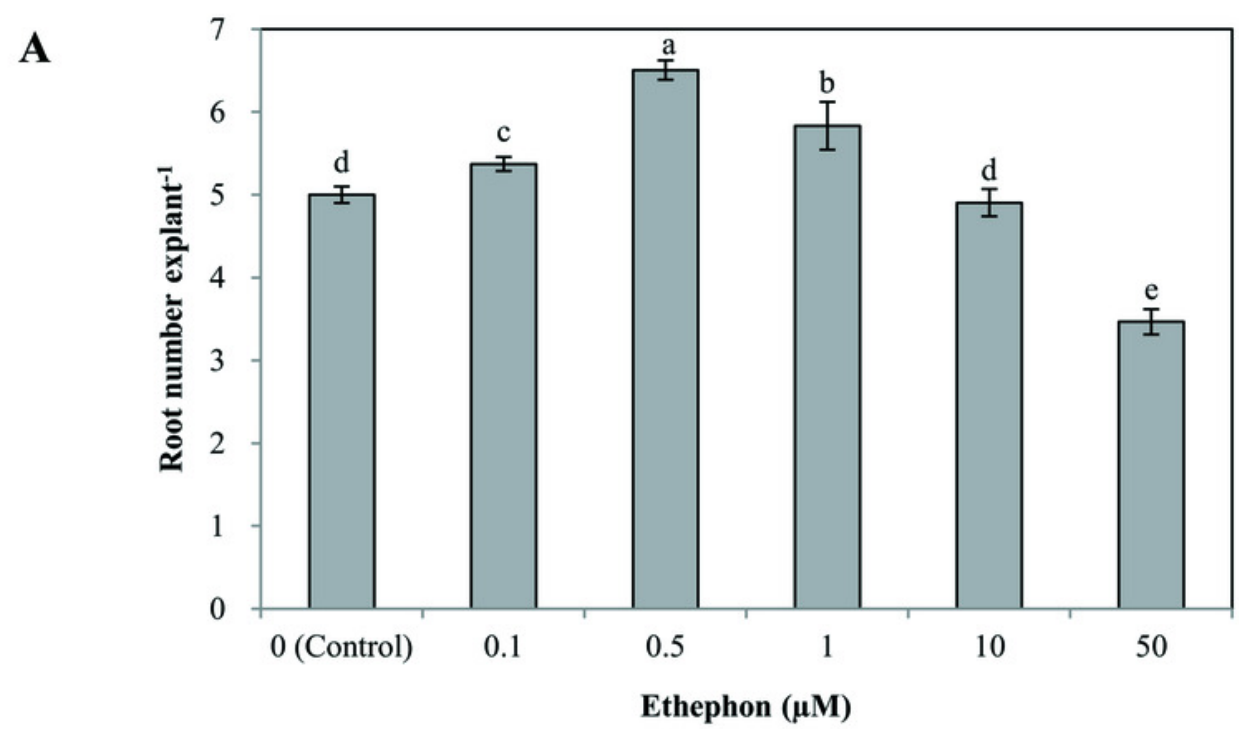

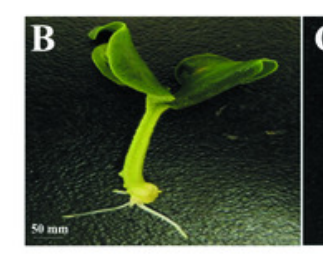

0 (Control)

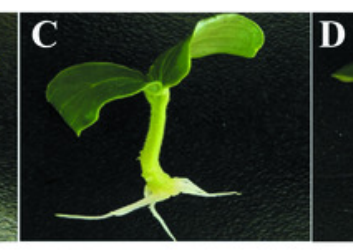

0.1

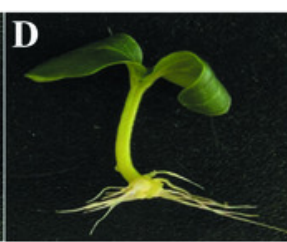

0.5

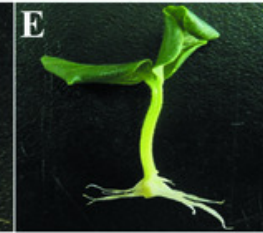

1

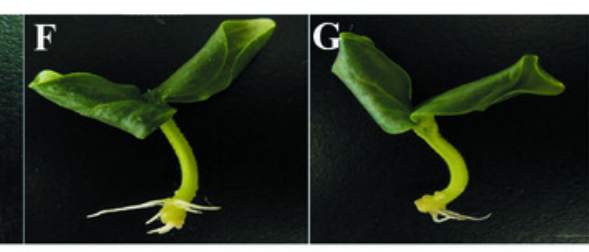

10
50 


\section{Figure 3}

Effects ETH inhibitor on $\mathrm{H}_{2}$-induced adventitious root development.

The primary root system was removed from hypocotyls of 7-day-old germinated cucumber. Explants of cucumber were incubated with $0.5 \mu \mathrm{M}$ ethephon, $50 \% \mathrm{HRW}, 50 \% \mathrm{HRW}+0.5 \mu \mathrm{M}$ ethephon, 50\% HRW + $1 \mu \mathrm{M} \mathrm{AVG}, 50 \% \mathrm{HRW}+0.1 \mu \mathrm{M} \mathrm{AgNO} / \mathrm{NaNO}_{3}$ and indicated for 7 days. The number $(\mathbf{A})$ of adventitious roots per explant were expressed as mean \pm SE $(n=20$ explants from each of four independent experiments). Bars with different lowercase letters were significantly different (Duncan's multiple range test, $P<0.05$. Photographs (B-G) show hypocotyl explants after 7 days of the treatments indicated.

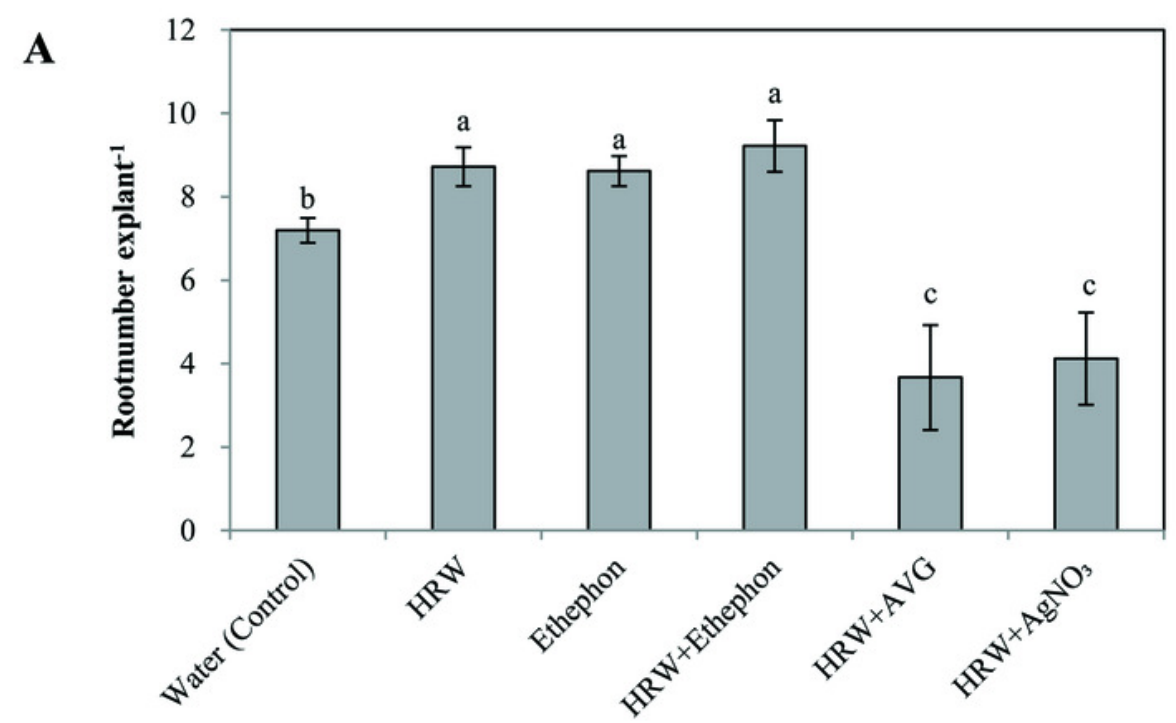

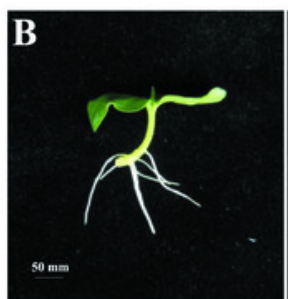

Water (Control)

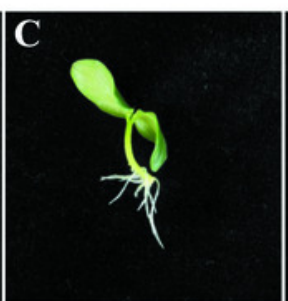

HRW

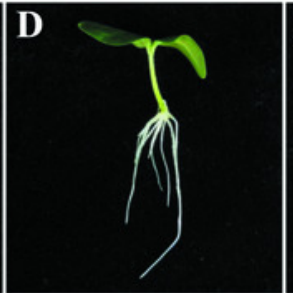

Ethephon

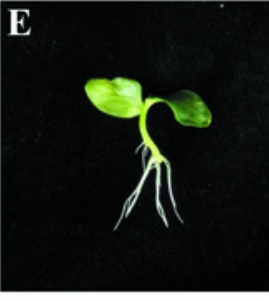

HRW+Ethephon

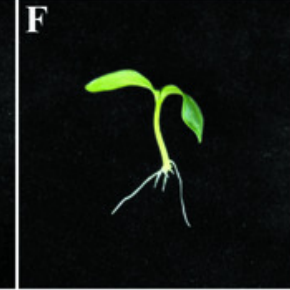

HRW+AVG

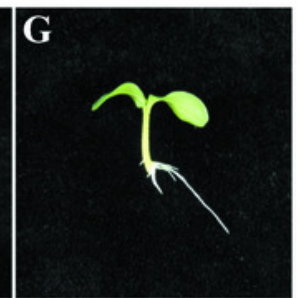

HRW+AgNO3 
Figure 4

The effect of HRW on the ETH production (A) and on the expression level (B) of two ETHrelated genes in cucumber explant.

The values (means $\pm \mathrm{SE}$ ) are the average of three independent experiments. Bars with an asterisk presents significant $(P<0.05)$, and two asterisks presents very significant $(P<$ $0.01)$.

A

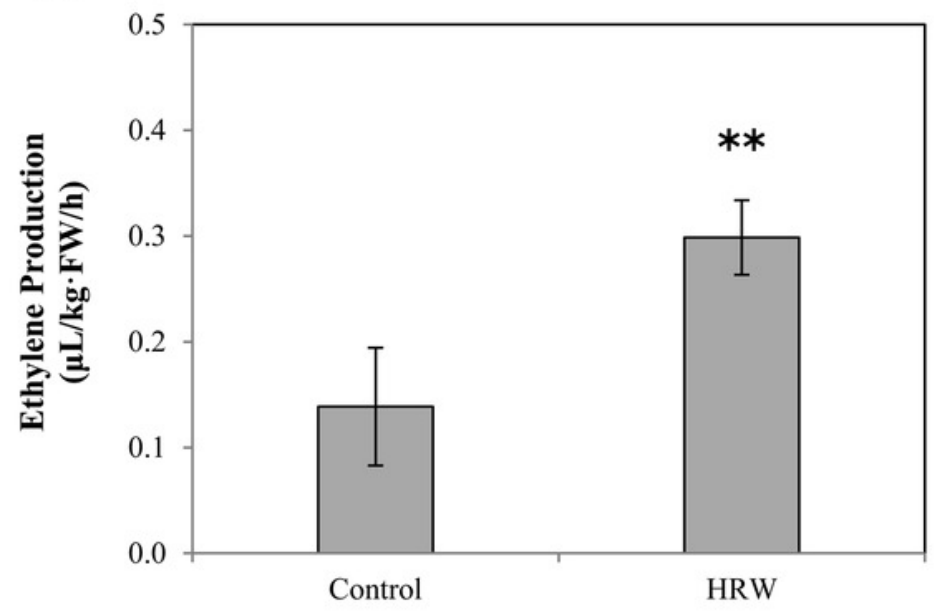

B

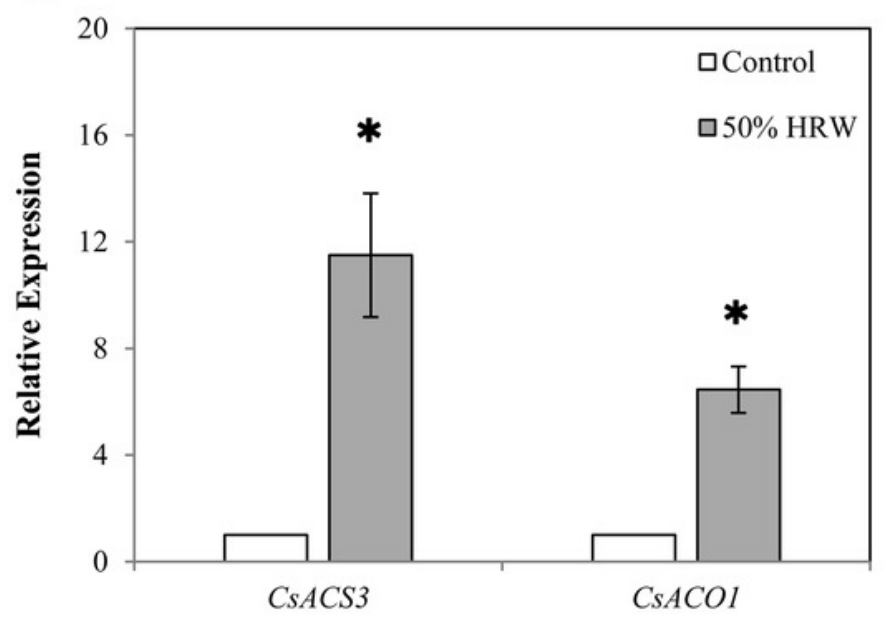


Figure 5

Separation of the total proteins extracted from the explants of cucumber on 2-DE gels over the $\mathrm{pH}$ range 4-7.

Each map depicts one representative gel (of three replicates). A total of 48 protein spots showing difference are numbered on the gels. Arrows indicate the protein spots that were positively identified. A, Control. B, HRW. C, ethephon. D, HRW + AVG.

A

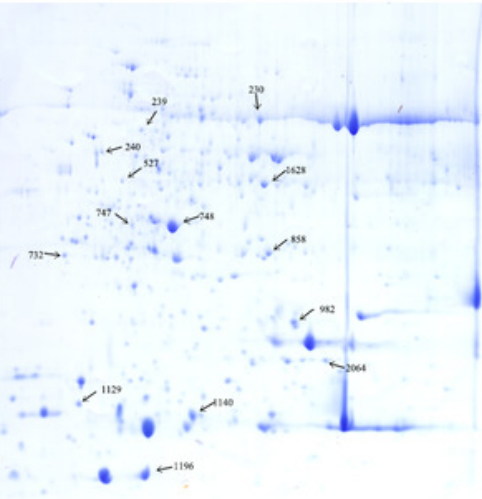

C

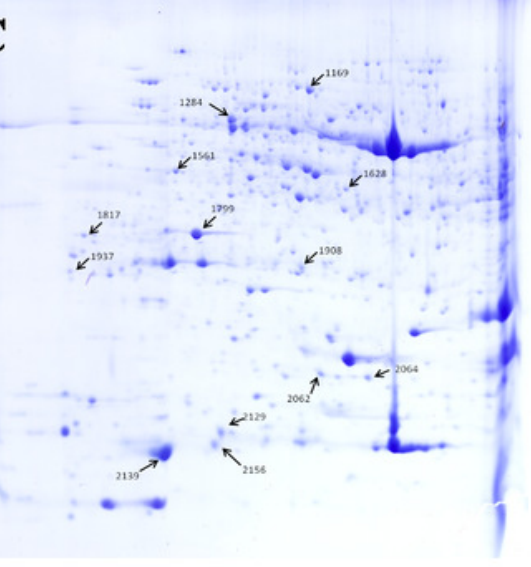

B

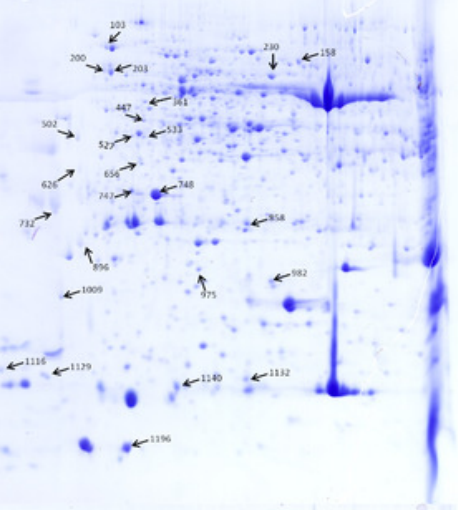

D

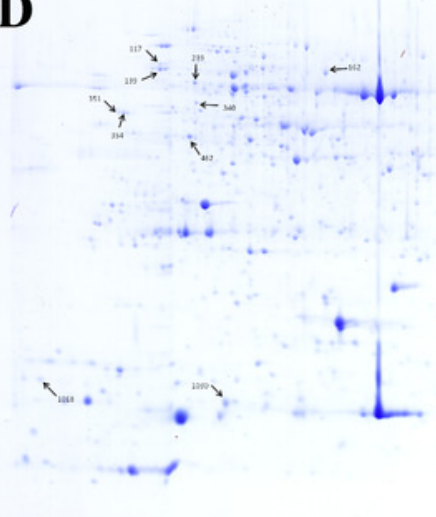


Figure 6

The functional classification and distribution of all 41 identified proteins.

Unknown proteins include those whose functions have not been described. 


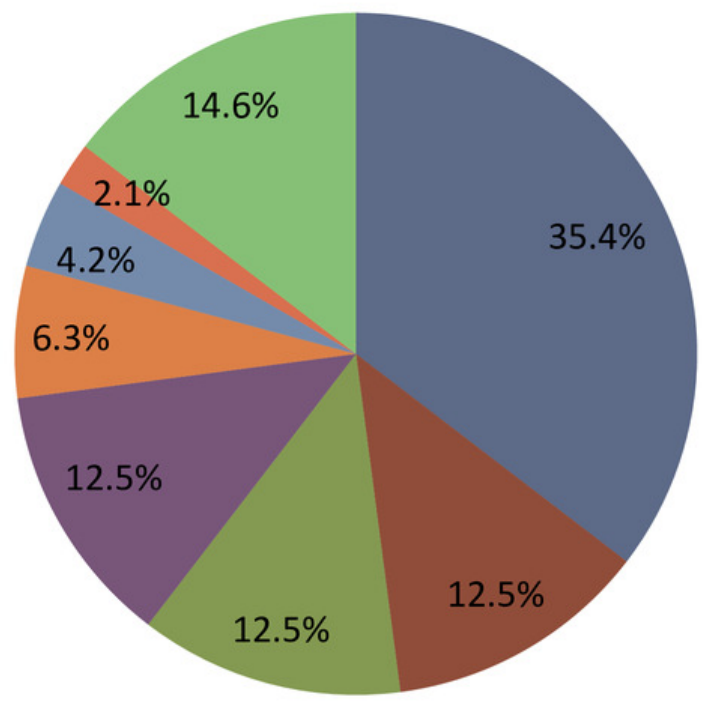

- Photosynthesis

- Energy metabolism

- Translation and transcription

- Protein folding, modification and degradation

$\square$ Stress and defence response

- Amino and metabolism

n Cellular cytoskeleton

匹 Unknown 


\section{Figure 7}

The gene ontology (GO) analysis of the identified proteins.

Information of number and percentage of involved proteins in a term are shown in left and right y-axis.

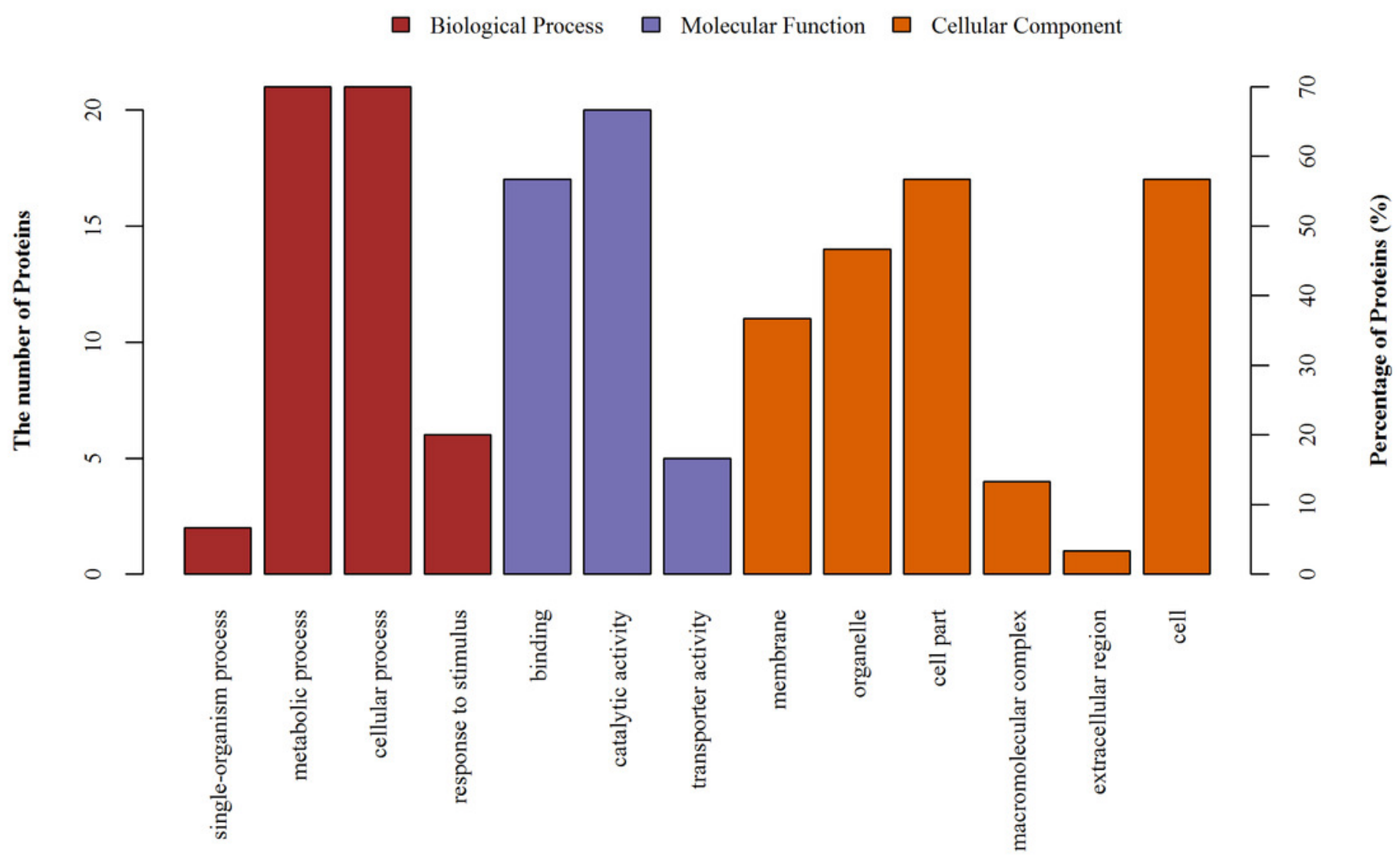


Figure 8

The effect of ETH and HRW on the expression levels of rbcS (A), SBPase (B), TDH (C), OEE1 (D), CAPX (E) and PDI (F).

The values (means $\pm \mathrm{SE}$ ) are the average of three independent experiments. Bars with different lowercase letters were significantly different by Duncan's multiple range test $(\mathrm{P}<$ 0.05). 

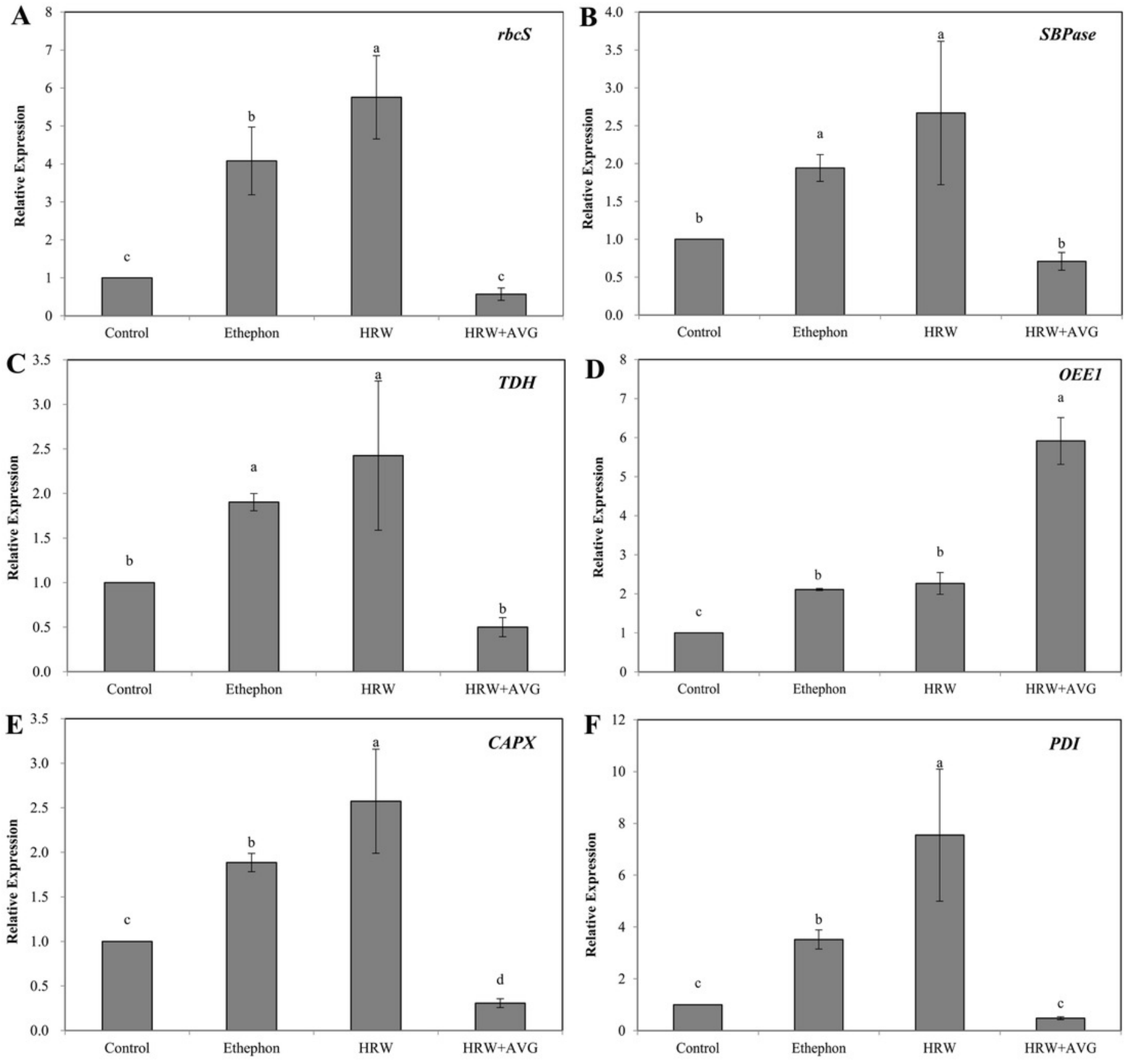